\title{
Macromolecular Synthesis in the Digestive and Respiratory Systems
}

\author{
Tetsuji Nagata1,2 \\ ${ }^{1}$ Department of Anatomy and Cell Biology, \\ Shinshu University School of Medicine, Matsumoto \\ ${ }^{2}$ Shinshu Institute of Alternative Medicine and Welfare, Nagano \\ Japan
}

\section{Introduction}

This second chapter deals with the second parts of the application of microscopic radioautography to some of the visceral organ systems. The visceral organs can be divided into 5 organ systems according to anatomy and histology, i.e., the digestive system, the respiratory system, the urinary system, the reproductive system and the endocrine system. Among of them the digestive system consists of 2 parts, i.e., the digestive tract and the digestive glands. The former consists of simple tube structures such as the oral cavity, the esophagus, the stomach and the intestines, while the latter consists of complicated glandular structures such as the large digestive glands, i.e., the liver and the pancreas, while the respiratory system consists of 2 parts, one the respiratory tract such as the nose, the pharynx, the trachea, the bronchus, and final essential part the lungs. This chapter deals with the digestive organs and the respiratory organs, respectively.

\subsection{Macromolecular synthesis in the digestive system}

The digestive system consists of the digestive tract and the digestive glands. The digestive tract can be divided into several portions, from the upper part to the lower part, i.e., the oral cavity, the pharynx, the esophagus, the stomach, the small and large intestines and the anus, while the digestive glands consist of the large glands such as the salivary glands, the liver and the pancreas and the small glands affiliated to the digestive tracts in the gastrointestinal walls such as the gastric glands including the fundic gland and the pyloric gland, the intestinal glands of Lieberkühn and the duodenal glands of Brunner. We have published many papers from our laboratory dealing with the macromolecular synthesis in respective digestive organs from the oral cavity to the gastrointestinal tracts and the digestive glands (Nagata 1992, 1993a,b, 1994a,b,c,d,e, 1995a,b,c,d, 1996a,b,c, 1999a,b,c, 2002, Nagata et al. 1979, 1982a, 2000a, Chen et al. 1995). The outline of the results concerning to the macromolecular synthesis in the digestive organs should be here described in the order of systematic anatomy and special histology as follows.

\subsubsection{Macromolecular synthesis in the oral cavity}

The oral cavity consists of the lips, tongue, teeth, and the salivary glands. The DNA synthesis of mucosal epithelia of the 2 upper and lower lips and the tongue as well as the 3 
large salivary glands and many small glands of aging mice from fetal day 19 to postnatal 2 years were studied by LM and EM RAG labeled with ${ }^{3} \mathrm{H}$-thymidine. The glucide and glycoprotein syntheses by ${ }^{3} \mathrm{H}$-glucosamine and radiosulfate incorporations of the submandibular and sublingual glands of aging mice were also studied.

\subsubsection{The DNA synthesis in the oral cavity}

We first studied the DNA synthesis of the submandibular glands in 10 groups of aging mice at various ages from embryo to postnatal 2 years (Chen et al. 1995, Nagata et al. 2000a). The submandibular gland of male mouse embryonic day 19 consisted of the glandular acini and duct system (Fig. 5A). The duct system was composed of the juxtaacinar cells (JA), the intercalated duct cells (ICD) and the striated duct cells (SD). Many labeled developing acinar cells (AC), JA and ICD cells were observed. At postnatal day 1 to 3 (Fig. 5B), there was more JA cells and secretory granules than those of former stage. JA cells were cuboidal cells in shape, characterized by small darkly stained granules in the supranuclear cytoplasm and by basophilic mitochondria mostly at the basal half of the cells. JA cells were present at the acinar-intercalated duct junction of the mouse submandibular gland. Many labeled AC, JA, ICD and SD cells were also observed by electron microscopy (Fig. 5C). At postnatal 2 weeks to 3 months, developing immature acinar cells gradually matured to acinar cells, and JA cells increased and granular convoluted duct cells (GCT) appeared.

At postnatal 6 months to 2 years, the GCT cells were very well developed and were composed of the taller cells packed with many granules and became highly convoluted, and only a few labeled cells were found. The aging changes of frequency of 5 main individual cell types in submandibular glands of male mouse from embryonic day 19 to postnatal 2 years of age were counted. On embryonic day 19 of age, the gland consisted of developing acinar cells (49\%), intercalated duct cells (37\%), juxta-acinar (JA) cells (3\%), striated duct (SD) cells (11\%). At birth, JA cells increased rapidly to $32 \%$, thereafter decreased gradually. At 1 month of age, JA cells disappeared and granular convoluted tubule (GCT) cells appeared and increased rapidly in number with age. They reached a maximum at 6 months. Then they decreased gradually from 6-21 months. The quantity proportion of acini was relatively stable during these periods. The frequency of ICD cells (Fig. 5C) was the highest $(37 \%)$ at 1 day after birth. Thereafter it gradually decreased month by month and reached $2.6 \%$ at 21 months, while the ratio of SD cells persisted in 7\%-12\% from embryonic day 19 to postnatal 2 weeks and it disappeared at 3 months after birth. The proliferative activity of the cell population is expressed by the labeling index which is defined as the percentage of labeled nuclei with ${ }^{3} \mathrm{H}$-thymidine in a given cell population. The labeling index of the entire gland cells increased from $13.6 \%$ at embryonic 19 to $18.3 \%$ at neonate, when it reached the first peak (Fig. 6A, B). Then it declined to $2.2 \%$ at 1 week of age. A second small peak $(2.9 \%)$ occurred at 2 weeks. Thereafter, the labeling index decreased progressively to less than $1 \%$ at 4 weeks of age and then remained low. The analysis of the labeling indices of respective cell types revealed that the first peak at neonate was due to the increased labeling indices of AC, ICD and JA cells, and the second peak at 2 weeks was due to the increase of ICD and SD cells. Thereafter, the labeling index of ICD cells decreased steadily but remained higher than those of any other cell types. Since the labeling index of ICD cells was more than the other cell types and persisted for a long time, it was suggested that ICD cells concerned with the generation of other cell types (Nagata 2002). 

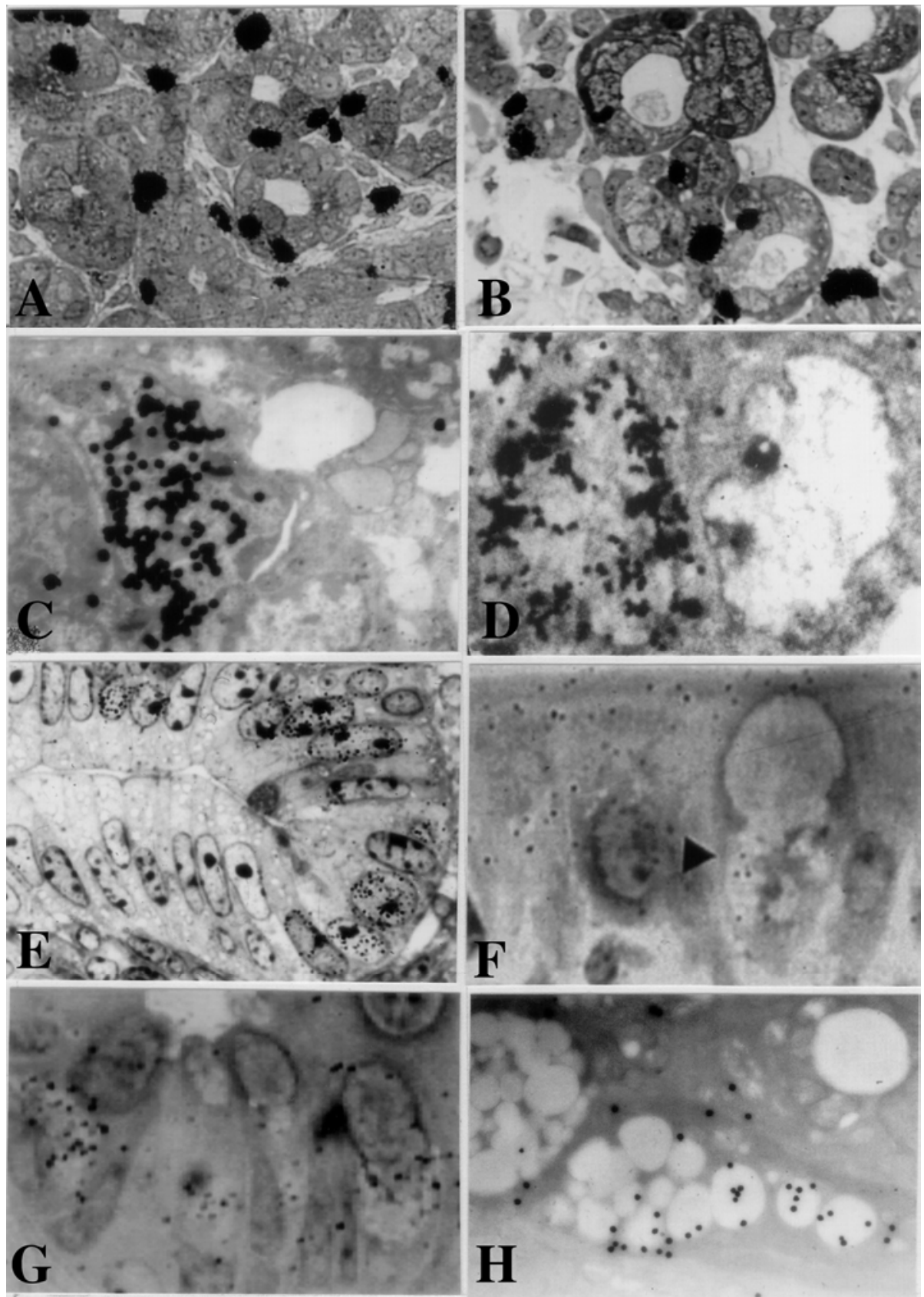

Fig. 6. LM and EM RAG of the digestive organs. From Nagata, T.: Radioautographology, General and Special. In, Prog. Histochem. Cytochem. Vol. 37, No. 2, p. 118, 2002, Urban \& Fischer, Jena, Germany 
Fig. 6A. LMRAG of the submandibular gland of male mouse embryonic day 19 labeled with ${ }^{3} \mathrm{H}$-thymidine consisted with the glandular acini and duct system. The duct system was composed of juxtaacinar cells (JA), intercalated duct cells (ICD) and striated duct cells (ICD). Many labeled developing acinar cells (AC), JA and ICD cells were observed. $x 500$.

Fig. 6B. LMRAG of the submandibular gland at postnatal day 3, labeled with ${ }^{3} \mathrm{H}$-thymidine. There were more JA cells and secretory granules than those of former stage (Fig. 5A). x500. Fig. 6C. EMRAG of an ICD cell of a mouse at postnatal day 3, labeled with ${ }^{3} \mathrm{H}$-thymidine observed by electron microscopy. Many silver grains are observed over the nucleus of an ICD. $\times 10,000$.

Fig. 6D. EMRAG of the esophageal epithelial cells of a newborn mouse at postnatal day 1, labeled with ${ }^{3} \mathrm{H}$-thymidine. Many silver grains are observed over one of the nuclei at left. $\mathrm{x} 10,000$.

Fig. 6E. LMRAG of the colonic epithelial cells of a mouse embryo at fetal day 19, labeled with ${ }^{3} \mathrm{H}$-thymidine. Many silver grains are observed over the nuclei of several epithelial cells in the bottom of the crypt. $x 800$.

Fig. 6F. LMRAG of the ileum epithelial cells labeled with ${ }^{3} \mathrm{H}$-glucosamine of an old mouse at postnatal 6 months. Many silver gains are localized over the Golgi region of the 3 goblet cells as well as over the cytoplasm of several absorptive columnar epithelial cells. $x 1,000$. Fig. 6G. LMRAG of the colonic epithelial cells of a mouse at postnatal month 1, labeled with ${ }_{35} \mathrm{SO}_{4}$ in vitro and radioautographed. $x 1,000$.

Fig. $6 \mathrm{H}$. EMRAG of a goblet cell in the deeper crypt of the colonic epithelial cells of an adult mouse after injection of $35 \mathrm{SO}_{4}$ and radioautographed. Many silver grains are observed over the Golgi region and mucous droplets of the goblet cell, demonstrating the incorporation of radiosulfate into sulfomucins. $x 4,800$.

\subsubsection{The glucide synthesis in the oral cavity}

We studied the incorporations of ${ }^{3} \mathrm{H}$-glucosamine in the submandibular glands of 10 groups of litter mice at various ages. The animals from embryonic day 19, postnatal day 1, 3, 7, 14, and 1, 3, 6 months to 1 and 2 years were sacrificed after administration of ${ }^{3} \mathrm{H}$-glucosamine and the submandibular glands were processed for LM and EM RAG (Watanabe et al. 1997, Nagata 2002). The results showed that the silver grains appeared over the endoplasmic reticulum, Golgi apparatus and the secretory granules of the acinar cells, demonstrating the glycoprotein synthesis in these cells. Grain counting revealed that the counts increased from the fetal stage at embryonic day 19 to postnatal day 1 to $3,7,14$, reaching the peak at day 14 , then decreased to month 1, 3, 6, to year 1 and 2, showing the aging changes, inverse proportion to DNA synthesis of these cells.

On the other hand, the sulfate uptake and accumulation in sulfomucin in several digestive organs of mice were also studied by light microscopic radioautography (Nagata and Kawahara 1999, Nagata et al. 1999b). Two litters of normal ddY mice 30 days after birth, each consisting of 3 animals, were studied. One litter of animals was sacrificed at $30 \mathrm{~min}$ after the intraperitoneal injections with phosphate buffered $\mathrm{Na}_{2}{ }^{35} \mathrm{SO}_{4}$, and the other litter animals were sacrificed at $12 \mathrm{hr}$ after the injections. Then the submandibular glands and the sublingual glands were taken out, fixed, embedded in epoxy resin, sectioned, radioautographed and analyzed by light microscopy. As the results, many silver grains were observed on serous cells of the salivary glands at $30 \mathrm{~min}$ and $12 \mathrm{hr}$ after the injections 
(10-20/cell). The numbers of silver grains at $30 \mathrm{~min}$ were less than those at $12 \mathrm{hr}$. From the results, it was concluded that glycoprotein synthesis was demonstrated in both the submandibular and sublingual glands by radiosulfate incorporation. In the salivary glands the silver grains were more observed in serous cells than mucous cells at $30 \mathrm{~min}$, while in mucous cells more at $12 \mathrm{hr}$ than $30 \mathrm{~min}$ after the injection. These results show the time difference of glycoprotein synthesis in the two salivary glands, showing inverse proportion to DNA synthesis of these cells (Watanabe et al. 1997, Nagata 2002).
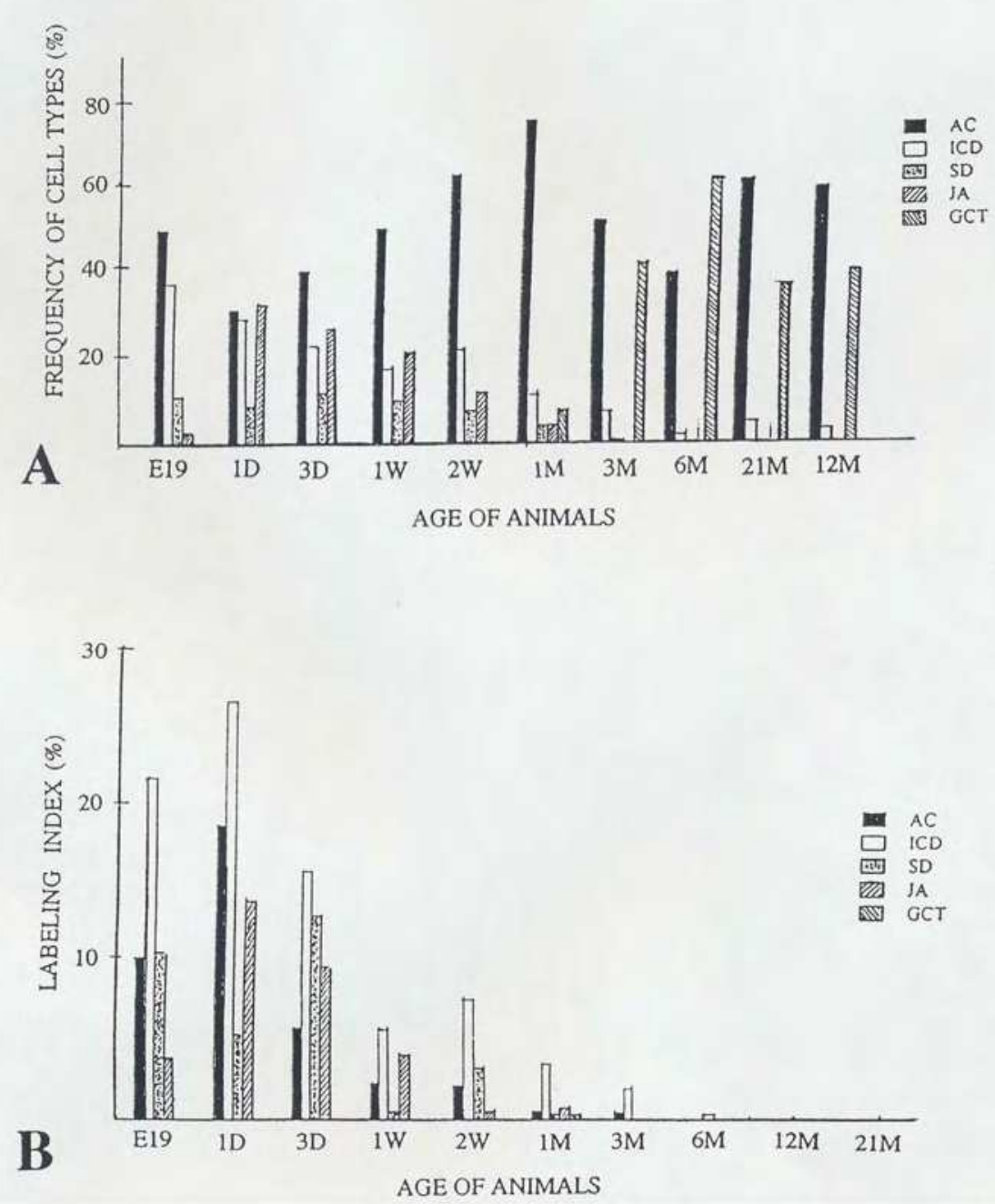

Fig. 7. Histogram showing the frequencies (A) and labeling indices (B) of the five individual cell types in the submandibular glands of male ddY mice at respective ages. From Nagata, T.: Radioautographology, General and Special. In, Prog. Histochem. Cytochem. Vol. 37, No. 2, p.118, 2002, Urban \& Fischer, Jena, Germany 


\subsection{Macromolecular synthesis in the esophagus}

The esophagus is the characteristic digestive tract including all the layers, the mucous membrane covered with the stratified squamous epithelia, the submucosa, the muscular layer and the serosa or adventitia. We studied the DNA synthesis of the esophagus of aging mice labeled with ${ }^{3} \mathrm{H}$-thymidine by LM and EM RAG (Duan et al. 1992, 1993). The labeled cells were mainly found in the basal layer of the esophageal epithelium (Fig. 6D). By electron microscopy the nuclei and nucleoli of labeled cells were larger than those of unlabeled cells, but contained fewer cell organelles (Duan et al. 1993). The labeling indices in respective aging groups showed a peak at postnatal day 1 and decreased with aging keeping a constant level around a few \% from 6 months to 2 years after birth.

\subsection{Macromolecular synthesis in the stomach}

The stomach consists of the mucosa covered with the surface epithelia of the columnar epithelia, including the gastric glands, the submucosa, the muscular layer and the serosa.

\subsubsection{DNA synthesis in the stomach}

As for the turnover of fundic glandular cells shown by ${ }^{3} \mathrm{H}$-thymidine radioautography, it was extensively investigated with LM RAG by Leblond and co-workers (Leblond 1981, Leblond et al. 1958). They demonstrated that the DNA synthesis in the stomach increased at perinatal stages and decreased due to aging and senescence. However, the activity never reached zero but low activity continued until senescence. We studied the macromolecular synthesis including DNA, RNA, protein and glycoproteins in the gastric mucosa of both human and animal tissues by LM and EMRAG (Sato et al. 1977). As for the DNA synthesis, we obtained the same results as Leblond et al $(1958,1981)$. We have not carried out this study so much. Therefore, the minute details will be here omitted.

\subsubsection{Protein synthesis in the stomach}

We observed the secretion process in G-cells by EM RAG using ${ }^{3} \mathrm{H}$-amino acid (Sato 1978, Sato et al. 1977, Komiyama et al. 1978). When the stomach tissues were taken out from the adult Wistar rats at postnatal month 1 and were labeled with either ${ }^{3} \mathrm{H}$-glutamic acid or ${ }^{3} \mathrm{H}$-glycine in vitro at varying time intervals, silver grains in the EM radioautograms appeared first over the Golgi zones, then migrated to secretory granules and were stored in the cytoplasm, suggesting the secretory kinetics. We also studied the mechanism of serum albumin passing through the gastric epithelial cells into the gastric cells by EM RAG (Sato et al. 1977). When adult Wistar rat stomach tissues were labeled with 132I-albumin in vitro at varying time intervals, silver grains in the radioautograms appeared over rough endoplasmic reticulum within $3 \mathrm{~min}$, then moved to the Golgi apparatus in $10 \mathrm{~min}$, and on to secretory granules and into the lumen in $30 \mathrm{~min}$, suggesting the pathway of serum albumin absorption from the blood vessels through the gastric mucous epithelial cells into the gastric lumen (Komiyama et al. 1978). These results demonstrated that the stomach cells of adult rats synthesized proteins and secreted. However, aging changes of these protein synthesis between the young and senescent animal were not yet completed. 


\subsubsection{The glucide synthesis in the stomach}

When incorporation of radiosulfate into sulfated complex carbohydrate in rat stomach was studied by labeling with ${ }^{35} \mathrm{SO}_{4}$ in vivo, silver grains appeared over the glandular cells of the pyloric gland but not those of the fundic gland, demonstrating the mucous synthesis in the former glands (Nagata et al. 1988a, Nagata and Kawahara 1999). The radiosulfate uptake and accumulation in the stomach of mouse were also studied by light microscopic radioautography (Nagata et al. 1999b). Two litters of normal ddY mice 30 days after birth, each consisting of 3 animals, were studied. One litter animals were sacrificed at $30 \mathrm{~min}$ after the intraperitoneal injections with phosphate buffered $\mathrm{Na}_{2}{ }^{35} \mathrm{SO}_{4}$, and the other litter animals were sacrificed $12 \mathrm{hr}$ after the injections. Then the antrum and the fundus tissues of the stomachs were taken out. The tissues were fixed, dehydrated, embedded in epoxy resin, sectioned, radioautographed and analyzed. As the results, many silver grains were observed on the mucosa and submucosa of the stomach at $30 \mathrm{~min}$ after the injection. Then at $12 \mathrm{hr}$ after the injection silver grains were observed on some of the fundic glands. The numbers of silver grains observed in the stomach especially over the pyloric glands at $30 \mathrm{~min}$ (a few per cell) were less than those (several per cell) at $12 \mathrm{hr}$. The results showed the time difference of glycoprotein synthesis in the stomach, showing inverse proportion to DNA synthesis (Nagata and Kawahara 1999, Nagata 2002).

\subsection{Macromolecular synthesis in the intestines}

The intestines of mammals are divided into 2 portions, small and large intestines, which can be further divided into several portions, the small intestines into the duodenum, the jejunum and the ileum, while the large intestines into the caecum, the appendix vermiformis, the colon and the rectum. The intestinal tracts in any portions consist of the mucosa covered with columnar epithelial cells including absorptive and secretory cells, the submucosa, the smooth muscular layer and the serosa. We studied the macromolecular synthesis, both the DNA and the proteins in the intestines by LM and EMRAG mainly in the epithelial cells (Nagata 2002).

\subsubsection{The DNA synthesis in the intestines}

We studied the DNA synthesis in the intestines by LM and EMRAG mainly in the epithelial cells (Nagata 2002). The DNA synthesis of small and large intestines of mice were studied by ${ }^{3} \mathrm{H}$-thymidine RAG (Fig. 6E). The cells labeled with ${ }^{3} \mathrm{H}$-thymidine were localized in the crypts of both small and large intestines, a region defined as the proliferative zone. In the colon of aging mice from fetal to postnatal 2 years, the labeled cells in the columnar epithelia were frequently found in the perinatal groups from embryo to postnatal day 1 . However, the labeling indices became constant from the suckling period until senescence (Morita 1993, Morita et al. 1994). On the other hand, we examined the labeling indices of respective cell types in each layer of mouse colon such as columnar epithelial cells, lamina propria, lamina muscularis mucosae, tunica submucosa, inner circular muscle layer, outer longitudinal muscle layer, outer connective tissue and serous membrane of the colon and found that most labeling indices decreased after birth to 2 months except the epithelial cells which kept constant value to senescence (Jin and Nagata 1995a,b, Jin 1996) (Fig. 8). Similar results were also obtained from the cecal tissues of mouse by LM and EMRAG. We also studied immunostaining for PCNA/cyclin and compared to the results obtained from RAG (Morita 
et al. 1994). The colonic tissues of litter mice of six aging groups from the embryonic day 19 , to newborn postnatal day 1, 5, 21, adult 2 months and senescent 12 months were fixed in methacarn solution, sectioned and immunostained for cyclin proliferating nuclear antigen (PCNA/cyclin) with the monoclonal antibody and the avidin-biotin peroxidase complex technique. The reaction appeared in the colonic epithelium from G1 to S phase of the cell cycle. The immunostaining positive cells were localized in the crypts of colons similarly to the labeled cells with ${ }^{3} \mathrm{H}$-thymidine by radioautography, a region defined as the proliferative zone. The positive cells in the columnar epithelia were frequently found in the perinatal groups from embryo to postnatal day 1 , and became constant from postnatal day 5 until senescence. Comparing the results by immunostaining with the labeling index by radioautography, it was found that the former was higher in each aging group than the latter. The reason for the difference should be due to that PCNA/cyclin positive cells included not only S-phase cells but also the late G1 cells.

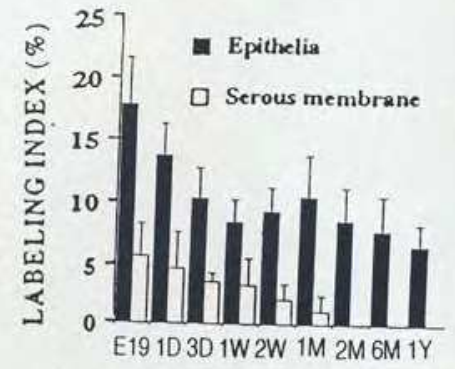

A AGE OF ANIMALS

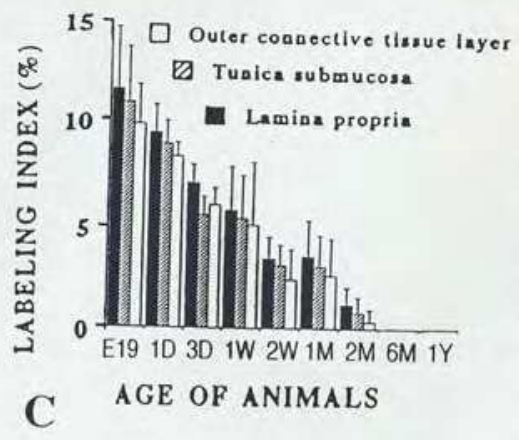

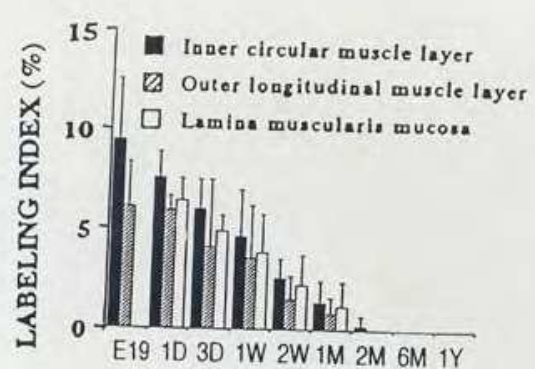

B AGE OF ANIMALS

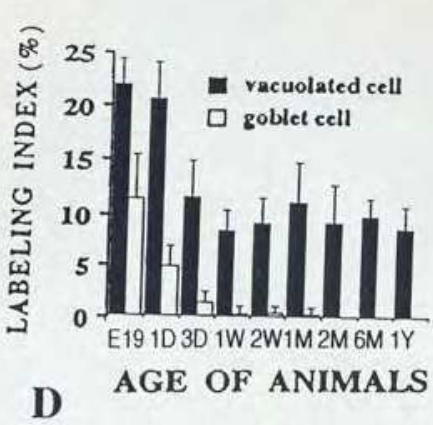

Fig. 8. Histogram showing aging changes of average labeling indices in respective tissue layers and cells of mouse colons at various ages from embryo to postnatal year 1, labeled with ${ }^{3} \mathrm{H}$-thyidine. From Nagata, T.: Radioautographology, General and Special. In, Prog. Histochem. Cytochem. Vol. 37, No. 2, p. 123, 2002, Urban \& Fischer, Jena, Germany

\subsubsection{The RNA synthesis in the intestines}

We studied the RNA synthesis of the small intestines of mice after feeding or refeeding under the restricted conditions (Nagata 1966). Five groups of ddY mice, each consisting of 5 individuals, total 25 , were injected with ${ }^{3} \mathrm{H}$-uridine, an RNA precursor, and sacrificed at 
different time intervals after feeding. The animals of the first group were injected with ${ }^{3} \mathrm{H}$ uridine at 9 a.m. and fed at 10 a.m. for $30 \mathrm{~min}$. and sacrificed at 11 a.m. 1 hour after the feeding and 2 hours after the injection, the $2^{\text {nd }}$ group was sacrificed at 1 p.m. 3 hours after feeding and 4 hours after the injection, the $3^{\text {rd }}$ group at 5 p.m., 7 and 8 hours later, the $4^{\text {th }}$ group at 9 a.m. on the next day 23 and 24 hours later, and finally the $5^{\text {th }}$ group at 1 . p.m. on the next day 3 hours after refeeding and 28 hours after the injection. Then, the jejunums obtained from each animal were prepared for isolated cell radioautograms according to Nagata et al. (1961). The results demonstrated that the grain counts in mononucleate villus cells reached the maximum (20-30 grains per cell) 4 hours after injection and decreased (10$20 /$ cell) after 28 hours, while the counts in mononucleate villus cells only increased gradually from 4 hours (10/cell) to 28 hours (20/cell). In contrast to this, the grain counts of binucleate cells which appeared in villus cells increased parallely to the mononucleate villus cells (10-20/cell). It was concluded that the RNA synthesis in the jejunal epithelial cells was high in the following order: mononucleate crypt cells, binucleate cells and mononucleate villus cells. These results revealed that the feeding or refeeding affected the RNA synthesis of the intestinal epithelial cells (Nagata 1966).

\subsubsection{The protein synthesis in the intestines}

We first studied the incorporations of ${ }^{3} \mathrm{H}$-leucine and ${ }^{3} \mathrm{H}$-tryptophane in mouse small intestines in connection to the binuclearity before and after feeding (Nagata 1967b). The results showed that the incorporations of both amino acids were greater in binucleate intestinal epithelial columnar cells than mononucleate villus and crypt cells at both before and after feeding. However, the aging changes of these incorporations were not studied.

\subsubsection{The glucide synthesis in the intestines}

We also studied the aging changes of glucide synthesis by ${ }^{3} \mathrm{H}$-glucosamine uptake in the small intestines of mouse (Morita 1993), and found that the silver grains in the ileum columnar epithelial cells were mainly localized over the brush borders and the Golgi regions in these cells (Fig. 6F). The grain counting revealed that the numbers of silver grains over the brush borders and cytoplasm of the columnar epithelial cells increased in the villi (10-15/cell) than in the crypts (1-2/cell) from 6 months up to 2 years due to aging. The grain counting in other cell types also revealed that the number of silver grains in goblet cells, basal granulate cells, Paneth cells increased by aging, but did not in the undifferentiated cells.

The glycoprotein synthesis in goblet cells as well as in absorptive epithelial cells was also studied using ${ }^{35} \mathrm{SO}_{4}$ incorporation in the duodenums, the jejunums and the colons of adult mice at varying time intervals at 30,60, and $180 \mathrm{~min}$ after the administration (Nagata et al. 1988a, Nagata and Kawahara 1999, Nagata et al. 1999b). Silver grains were localized over the columnar absorptive cells and the goblet cells, especially over the Golgi regions and mucous granules of the goblet cells. By EM RAG the intracellular localization of silver grains in goblet cells was clearly shown in the Golgi apparatus. The results from grain counting revealed that the average grain counts were different in the upper and deeper regions of the crypts in the 4 portions and it was shown that silver grains over goblet cells in the lower region of the crypt transferred rapidly from $30 \mathrm{~min}$ to $180 \mathrm{~min}$, while they transferred slowly in goblet cells in the upper region of the colonic crypt, leading to the conclusion that the rates of transport and secretion of mucous products of the goblet cells at these two levels in 
the crypts were different. By EM RAG silver grains first appeared over the Golgi zone at 30 min. and then moved to the secretory granules at 60 and $180 \mathrm{~min}$. The incorporation of $\mathrm{Na}_{2}{ }^{35 \mathrm{SO}_{4}}$ into sulfated complex carbohydrate was investigated in the mouse small and large intestines by LM and EM RAG as well as in the submandibular glands and the stomachs. Quantitative differences have been observed in the relative uptake of radiosulfate in the various labeled cells of each organ. Incorporation by the colon in goblet cells exceeded that elsewhere in the deep goblet cells of the colonic crypts migration of label progressed during the time tested from the supranuclear Golgi region to the deep position of the goblet and then extended throughout the mucosubstance in the goblet in the superficial goblet cells of the colon. The radioautographic and cytochemical staining differences between secretory cells in the deeper region compared with the upper region of the colonic crypts are considered to reflect differences in the rate of transport of secretory products in the theca and the rate of secretion at the low levels in the crypt (Figs. 6G,H). These results showed the time differences of glycoprotein synthesis in respective organs. The sulfate uptake and accumulation in several mouse digestive organs were also studied by LM RAG. Two litters of normal ddY mice 30 days after birth, each consisting of 3 animals, were studied. One litter of animals was sacrificed $30 \mathrm{~min}$ after the intraperitoneal injections with phosphate buffered $\mathrm{Na}_{2}{ }^{35} \mathrm{SO}_{4}$, and the other litter animals were sacrificed $12 \mathrm{hr}$ after the injections. Then several digestive organs, the parotid gland, the submandibular gland, the sublingual gland, antrum and fundus of the stomach, the duodenum, the jejunum, the ileum, the caecum, the ascending colon and the descending colon were taken out and radioautographed. As the results, many silver grains were observed on villous cells and crypt cells of the small intestines and whole mucosa of the large intestines at $30 \mathrm{~min}$ after the injection. Then at 12 $\mathrm{hr}$ after the injection silver grains were observed on mucigen granules of goblet cells in the small intestines and the large intestines. The numbers of silver grains observed in respective organs at $30 \mathrm{~min}$ were less than those at $12 \mathrm{hr}$. From the results, it was concluded that the time difference of the glycoprotein synthesis was demonstrated in several digestive organs by radiosulfate incorporation, in reverse proportion to DNA synthesis. The total S contents in colonic goblet cells in upper and deeper regions of colonic crypts in aging mice were also analyzed by X-ray microanalysis (Nagata et al. 2000b, Nagata 2004). The results accorded well with the results from RAG (Nagata 2002) showing increase and decrease of mucosubstances in these cells due to development and aging to senescence.

\subsection{Macromolecular synthesis in the liver}

The liver is the largest gland in the human and the mammalian body and consists of several types of cells (Nagata 2010c). The hepatocyte is the main component of the liver, composing the liver parenchyma which form the hepatic lobules, surrounded by other types of cells such as the connective tissue cells, sinusoidal endothelial cells, satellite cells of Kupffer, Ito's fatstoring cells and bile epithelial cells. In the livers of perinatal animals, the liver tissues include hematopoietic cells such as erythroblasts, myeloblasts and magakaryocytes. We studied macromolecular synthesis by LM and EMRAG mainly in hepatocytes of rats and mice (Nagata 1993b, 1994a,b,c,d, 1995a,b,c, 1996a, 1997a, 1999c, 2002, 2003, 2006b, 2007a, 2009a,d,h,i, 2010c,h).

\subsubsection{The DNA synthesis in the liver}

We first studied the DNA synthesis in the liver tissues at various ages from embryo to postnatal 2 years (Nagata 1993a,b, 1994a,b,c,d, 1995a,b,c,d, 1996a,b,c,d, 1997a,b,c, 1998a,b,c, 
1999a,b,c, 2002, Nagata et al. 1977a, Nagata and Nawa 1966b). The results obtained from the tissues of 3 groups of animals injected respectively with 3 kinds of RI-labeled precursors, i.e. ${ }^{3} \mathrm{H}$-thymidine, ${ }^{3} \mathrm{H}$-uridine and ${ }^{3} \mathrm{H}$-leucine, were already reported as several original articles and reviews (Ma 1988, Ma and Nagata 1988a,b, 1990a,b, 2000, Ma et al. 1991, Nagata 1996a,b, 1997a, 1998a, 1999c, 2001c, 2002, 2003, 2006a,b, 2007a,b, 2009a,b,c,d) or as a monograph in the series of Prog. Histochem. Ccytochem (Nagata 2002, 2004, 2010c). Therefore, the results from the livers in aging mice should be briefly summarized in this article.

\subsubsection{The DNA synthesis in hepatocyte nuclei}

As for the nucleic acid synthesis in hepatocytes, we first studied the difference between the mononucleate and binucleate hepatocytes of adult rats, injected with ${ }^{3} \mathrm{H}$-thymidine and radioautographed (Nagata 1962, 1994d). The results showed that the frequency of labeled cells was greater in the mononucleate cells (Fig. 9A) than in the binucleate cells. The labeled binucleate cells were classified into two types, i.e., a hepatocyte whose one of the two nuclei was labeled and a hepatocyte whose two nuclei were labeled. The former was more frequently observed than the latter. Grain counts revealed that the amount of DNA synthesized in the binucleate cell whose one nucleus was labeled was the same as the mononucleate cell, while the total amount of DNA synthesized in the binucleate cell whose two nuclei were labeled was almost twice as that of the mononucleate cell. These results suggested that the two nuclei of binucleate hepatocytes synthesized DNA independently from each other.

On the other hand, LM and EMRAG of prenatal and postnatal normal mice at various ages labeled with ${ }^{3} \mathrm{H}$-thymidine revealed that many silver grains were localized over the nuclei of various cell types consisting the liver, i.e., hepatocytes (Fig. 9A), sinusoidal endothelial cells (Fig. 8B), Kupffer's cells, Ito's fat-storing cells, bile ductal epithelia cells, fibroblasts and hematopoietic cells (Ma 1988, Ma and Nagata 1988a,b, 1990, Nagata 1995a). In hematopoietic cells in the livers of perinatal animals, silver grains were observed over the nuclei of erythroblasts, myeloblasts, lymphoblasts and megekaryocytes. However, most hematopoietic cells disappeared on postnatal day 14. At fetal day 19, the liver tissues were chiefly consisted of hepatocytes and haematopoietic cells and no lobular orientation was observed. At postnatal day 1 and 3, lobular formation started and finally the hepatic lobules were formed at day 9 after birth.

During the perinatal period, almost all kinds of cells were labeled with ${ }^{3} \mathrm{H}$-thymidine. Percentage of labeled hepatocytes was the highest at fetal day 19, and rapidly decreased after birth to day 3. From day 9 to 14, percentage of labeled hepatocytes (labeling index) decreased gradually and finally to the lowest at 24 months (Fig. 10A). When the labeling indices of hepatocytes in 3 hepatic acinar zones were analyzed, the indices decreased in zone 2 (intermediate zone) and zone 3 (peripheral zone) on days 3 and 9 after birth, whereas they increased in zone 1 (central) on day 9, and then they altogether decreased from day 14 to 24 months (Fig. 10B). When the size and number of cell organelles in both labeled and unlabeled hepatocytes were estimated quantitatively by image analysis with an image analyzer, Digigramer G/A (Mutoh Kogyo Co. Ltd., Tokyo, Japan) on EMRAG, the area size of the cytoplasm, nucleus, mitochondria, endoplasmic reticulum, and the number of mitochondria in the unlabeled hepatocytes were more than the labeled cells (Ma and Nagata 1988a,b, Nagata 1995a,d). 


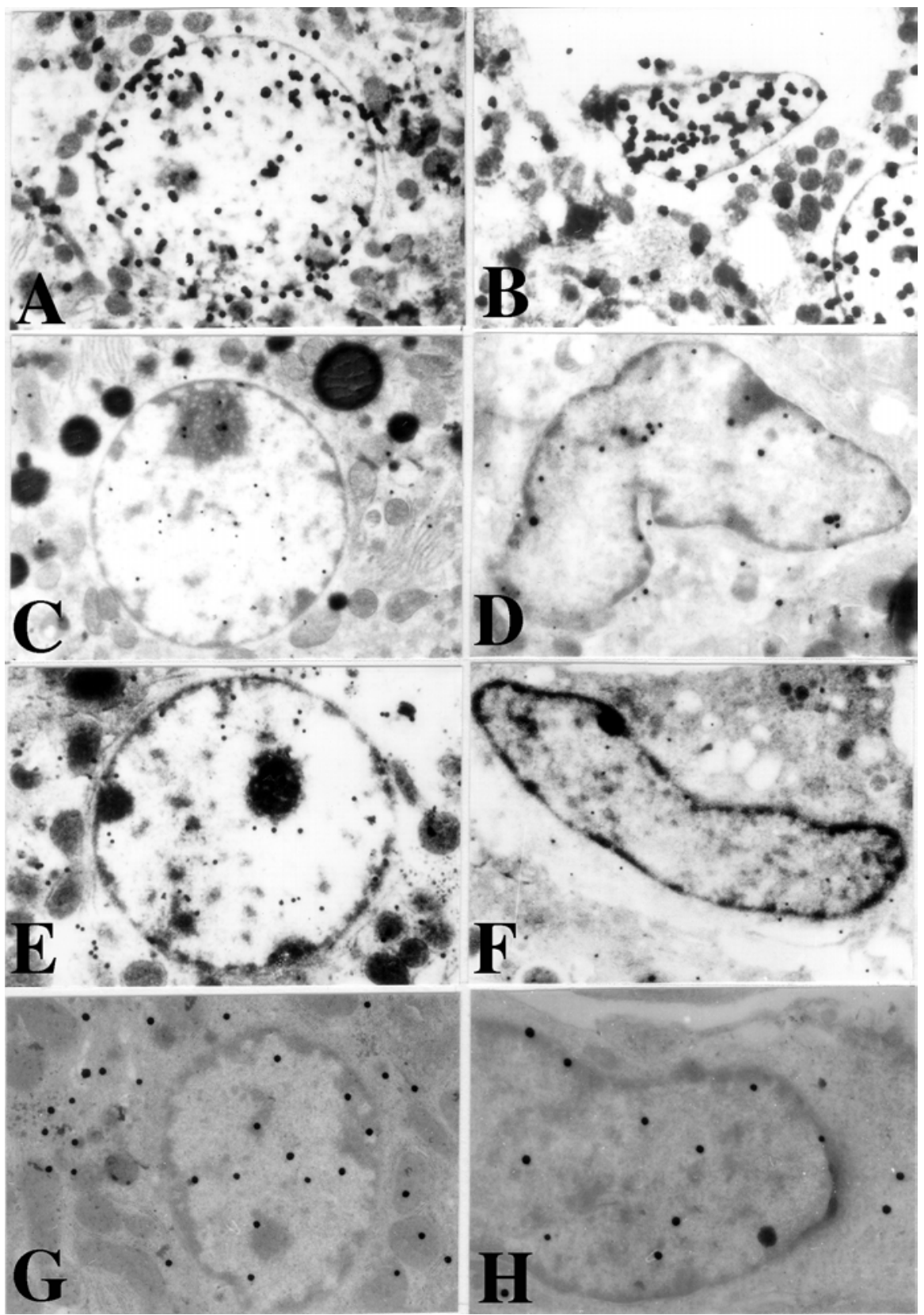

Fig. 9. EM RAG of the liver. From Nagata, T.: Radioautographology, General and Special. In, Prog. Histochem. Cytochem. Vol. 37, No. 2, p. 130, 2002, Urban \& Fischer, Jena, Germany Fig. 9A. EMRAG of a hepatocyte of the liver of a 14 day old mouse labeled with ${ }^{3} \mathrm{H}-$ thymidine. Many silver grains were observed over the nucleus and mitochondria. 
Fig. 9B. EM RAG of a sinusoidal endothelial cells of the liver of a 14 day old mouse labeled with ${ }^{3} \mathrm{H}$-thymidine. Many silver grains were observed over the nucleus and mitochondria. Fig. 9C. EM RAG of a hepatocyte of the liver of a 14 day old mouse labeled with ${ }^{3} \mathrm{H}$-uridine. Many silver grains were observed over the nucleus and mitochondria.

Fig. 9D. EM RAG of an Ito's fat-storing cell of the liver of a newborn 14 day old mouse labeled with ${ }^{3} \mathrm{H}$-uridine. Many silver grains were observed over the nucleus and mitochondria.

Fig. 9E. EM RAG of a hepatocyte of the liver of a 1 month old mouse labeled with ${ }^{3} \mathrm{H}-$ leucine. Many silver grains were observed over the nucleus and mitochondria.

Fig. 9F. EM RAG of a sinusoidal endothelial cells of the liver of a newborn 14 day old mouse labeled with ${ }^{3} \mathrm{H}-$ leucine. Many silver grains were observed over the nucleus and mitochondria. Fig. 9G. EMRAG of a hepatocyte of the liver of an adult 2 month old mouse labeled with ${ }^{3} \mathrm{H}-$ proline. Many silver grains were observed over the nucleus and mitochondria.

Fig. 9H. EMRAG of a Kupffer cell of the liver of a newborn 1 day old mouse labeled with ${ }^{3} \mathrm{H}$-proline. Many silver grains were observed over the nucleus and mitochondria.

These data demonstrated that the cell organelles of the hepatocytes which synthesized DNA were not well developed as compared to those not synthesizing DNA during the postnatal development. In some of unlabeled hepatocytes, several silver grains were occasionally observed localizing over mitochondria and peroxisomes as was formerly reported (Nagata et al. 1967a,b, 1982b). The mitochondrial DNA synthesis was first observed in cultured hepatocytes of chickens and mice in vitro (Nagata et al. 1967a,b). The percentages of labeled cells in other cell types in the liver of aging mice such as sinusoidal endothelial cells, Kupffer's cells, Ito's fat-storing cells, bile ductal epithelia cells and fibroblasts showed also decreases from perinatal period to postnatal 24 months.

\subsubsection{The DNA synthesis in hepatocyte mitochondria}

When we observed DNA synthesis in the nuclei of mononucleate and binucleate hepatocytes, we also observed DNA synthesis in hepatocyte mitochondria (Ma 1988, Ma and Nagata 1988a,b, 1990a,b, Nagata and Ma 2005a). The results of visual grain counts on the number of mitochondria labeled with silver grains obtained from 10 mononucleate hepatocytes of each animal labeled with ${ }^{3} \mathrm{H}$-thymidine demonstrating DNA synthesis in 8 aging groups at perinatal stages, prenatal embryo day 19, postnatal day 3, 9 and 14, month $1,6,12$ and 24, were obtained. The number of total mitochondria per cell increased from perinatal stage (35-50/cell) to postnatal month 6 (95-105/cell), reaching the maximum, decreased to month 24 (85-90/cell), while the number of labeled mitochondria per cell increased from perinatal stage to postnatal day 14, reaching the maximum, decreased to month 6 , then increased again to month 12 , reaching the second peak and decreased again to month 24 . Thus, the labeling indices in respective aging stages were calculated from the number of labeled mitochondria which showed an increase from perinatal stage to postnatal day 14, reaching the maximum and decreased to month 24 . The results showed that the numbers of labeled mitochondria with ${ }^{3} \mathrm{H}$-thymidine showing DNA synthesis increased from prenatal embryo day 19 (3.8/cell) to postnatal day 14 (6.2/cell), reaching the maximum, and then decreased to month 6 (3.7/cell) and again increased to year 1 (6.0/cell), while the labeling indices increased from prenatal day $19(11.8 \%)$ to postnatal day 14 $(16.9 \%)$, reaching the maximum, then decreased to month $6(4.1 \%)$, year $1(6.4 \%)$ and year 2 $(2.3 \%)$. The increase of the total number of mitochondria in mononucleate hepatocytes was stochastically significant $(\mathrm{P}<0.01)$, while the changes of number of labeled mitochondria and labeling index in mononucleate hepatocytes were not significant $(\mathrm{P}<0.01)$. 

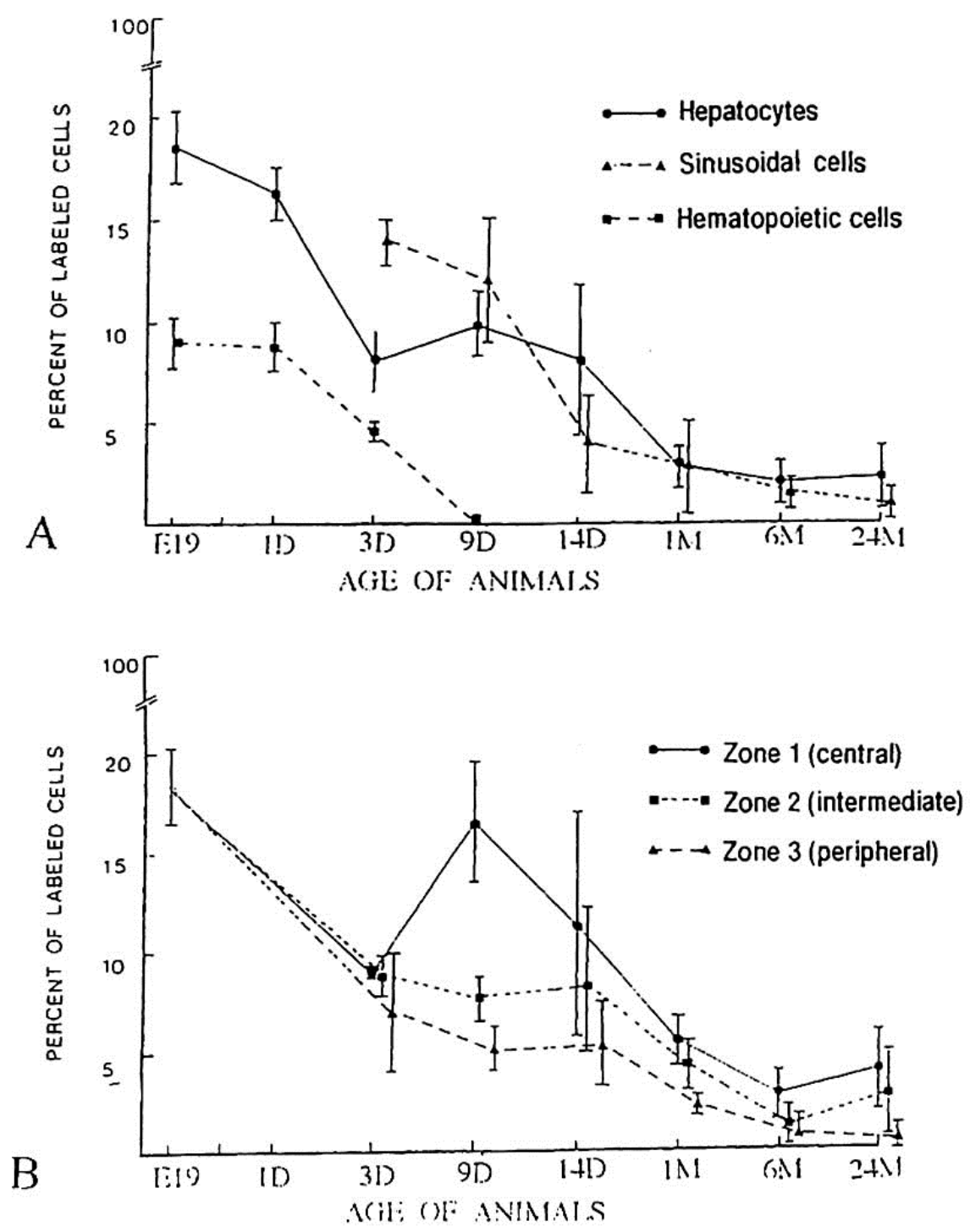

Fig. 10. Transitional curves of the labeling indices in the livers of aging mice after injection of ${ }^{3} \mathrm{H}$-thymine. Mean \pm Standard Deviation. From Nagata, T.: Special Cytochemistry in Cell Biology, In, Internat. Rev. Cytol. Vol. 211, No. 1, p. 92, 2001, Academic Press, San Diego, USA, London, UK.

Fig. 10A. Labeling indices of hepatocytes, sinusoidal endothelial cells and hematopoietic cells, respectively.

Fig. 10B. Labeling indices of hepatocytes, sinusoidal endothelial cells and hematopoietic cells, respectively. 
As for the binucleate hepatocytes, on the other hand, because the appearances of binucleate hepatocytes showing silver grains in their nuclei demonstrating DNA synthesis were not so many in the adult and senescent stages from postnatal month 1 to 24 , only binucleate cells at perinatal stages when reasonable numbers of labeled hepatocytes were found in respective groups were analyzed. The number of mitochondria in binucleate hepatocytes at postnatal day 1 to 14 kept around 80 (77-84/cell) which did not show such remarkable changes, neither increase nor decrease, as shown in mononucleate cells. Thus, the number of mitochondria per binucleate cell, the number of labeled mitochondria per binucleate cell and the labeling index of binucleate cell in 4 groups from postnatal day 1 to 14 were counted. The number of mitochondria and the number of labeled mitochondria were more in binucleate cells than mononucleate cells (Nagata 2007a,b,c,d,e, Nagata and Ma 2005a,b, Nagata et al. 1977a).

\subsubsection{The RNA synthesis in the liver}

The RNA synthesis in the liver was studied by ${ }^{3} \mathrm{H}$-uridine RAG. Silver grains due to RNA synthesis appeared over the nuclei and cytoplasm of hepatocytes.

\subsubsection{The RNA synthesis in hepatocyte nuclei}

When the RI-labeled precursor ${ }^{3} \mathrm{H}$-uridine was administered to experimental animals, or cultured cells were incubated in a medium containing ${ }^{3} \mathrm{H}$-uridine in vitro and LM RAG was prepared, silver grains first appeared over the chromatin of the nucleus and nucleolus of all the cells within several minutes, then silver grains spread over the cytoplasm within 30 minutes showing messenger RNA and ribosomal RNA (Nagata 1966, Nagata and Nawa 1966a,b, Nagata et al.1969).

We studied quantitative changes of RNA synthesis in the livers of adult mice before and after feeding by incorporations of ${ }^{3} \mathrm{H}$-uridine. Five groups of $\mathrm{ddY}$ mice, each consisting of 5 individuals, total 25 , were injected with ${ }^{3} \mathrm{H}$-uridine and sacrificed at different time intervals. The animals of the first group were injected with ${ }^{3} \mathrm{H}$-uridine at 9 a.m. and fed at 10 a.m. for 30 min. and sacrificed at 11 a.m. 1 hour after the feeding and 2 hours after the injection, the 2nd group was sacrificed at 1 p.m. 3 hours after feeding and 4 hours after the injection, the $3^{\text {rd }}$ group at 5 p.m., 7 and 8 hours later, the $4^{\text {th }}$ group at 9 a.m. on the next day 23 and 24 hours later, and finally the $5^{\text {th }}$ group at 1 . p.m. on the next day 3 hours after refeeding and 28 hours after the injection. Then, the livers were taken out from each animal, prepared for isolated cell radioautograms according to Nagata et al. (1961). The results demonstrated that the grain counts in both mononucleate and binucleate hepatocytes before feeding (15-25 grains per cell) increased 4 hours after feeding (30-40 grains per cell), reached the maximum in 24 hours (40-50 grains per cell), then decreased on the next day (30-40 grains per cell). It was concluded that the RNA synthesis in the binucleate hepatocytes was a little higher than the mononucleate hepatocytes at the same stages and both increased and decreased after feeding. These results revealed that the feeding or refeeding affected the RNA synthesis of the livers (Nagata 1966).

Then, we studied aging changes of ${ }^{3} \mathrm{H}$-uridine incorporation in the livers and pancreases of aging mice at various ages from prenatal embryos to postnatal aged mice to senescence at month 12 and 24 by LM and EMRAG (Ma and Nagata 1990b, Nagata 1999c). When aged mice were injected with ${ }^{3} \mathrm{H}$-uridine, $\mathrm{LM}$ and EM RAG showed that silver grains were localized over the nucleoli, nuclear chromatin (both euchromatin and heterochromatin), mitochondria and rough surfaced endoplasmic reticulum of hepatocytes (Fig. 9C) and other 
types of cells such as sinusoidal endothelial cells, Kupffer's cells, Ito's fat-storing cells (Fig. 9D), ductal epithelial cells, fibroblasts and haematopoietic cells in the livers at various ages. By quantitative analysis, the total number of silver grains in nucleus, nucleolus and cytoplasm of each hepatocyte increased gradually from fetal day 19 to postnatal days, reached the maximum at postnatal day $14(30 \%)$, then decreased to 24 months (5\%). The number of silver grains in nucleolus, when classified into two compartments, grains over granular components and those over fibrillar components both increased paralelly after birth, reached the maxima on day 14 (granular 6-7, fibrillar 1-2/per cell), then decreased to 24 months with aging. However, when the ratio (\%) of silver grains over euchromatin, heterochromatin of the nuclei and granular components and fibrillar components of the nucleoli are calculated, the ratio remained constant at each aging point.

\subsubsection{The RNA synthesis in hepatocyte mitochondria}

The intramitochondrial RNA synthesis was first found in the cultured HeLa cells and the cultured liver cells in vitro using EM RAG (Nagata 1972c, d). Then, it was also found in any other cells in either in vitro or vivo (Nagata et al. 1977c, Nagata 2002). Observing light microscopic radioautograms labeled with ${ }^{3} \mathrm{H}$-uridine, the silver grains were found over both the karyoplasm and cytoplasm of almost all the cells not only at the perinatal stages from embryo day 19 to postnatal day 1, 3, 9, 14, but also at the adult and senescent stages from postnatal month 1 to 2, 6, 12 and 24 (Nagata 2007a, c, d, e, f, Nagata and Ma 2005b). By electron microscopic observation, silver grains were detected in most mononucleate hepatocytes in respective aging groups localizing not only over euchromatin and nucleoli in the nuclei but also over many cell organelles such as endoplasmic reticulum, ribosomes, and mitochondria as well as cytoplasmic matrices from perinatal stage at embryonic day 19 , postnatal day $1,3,9,14$, to adult and senescent stages at postnatal month 1, 2, 12 and 24 . The silver grains were also observed in binucleate hepatocytes at postnatal day 1, 3, 9, 14, month $1,2,6,12$ and 24 . The localizations of silver grains over the mitochondria were mainly on the mitochondrial matrices but a few over the mitochondrial membranes and cristae when observed by high power magnification.

As the results, it was found that almost all the hepatocytes were labeled with silver grains showing RNA synthesis in their nuclei and mitochondria. Preliminary quantitative analysis on the number of mitochondria in 10 mononucleate hepatocytes whose nuclei were intensely labeled with many silver grains (more than 10 per nucleus) and other 10 mononucleate hepatocytes whose nuclei were not so intensely labeled (number of silver grains less than 9) in each aging group revealed that there was no significant difference between the number of mitochondria, number of labeled mitochondria and the labeling indices in both types of hepatocytes $(\mathrm{P}<0.01)$. Thus, the number of mitochondria and the labeling indices were calculated in 10 hepatocytes selected at random in each animal in respective aging stages regardless whether their nuclei were very intensely labeled or not. The results obtained from the number of mitochondria in mononucleate hepatocytes per cellular profile area showed an increase from the prenatal day (mean \pm standard deviation $26.2 \pm$ /cell) to postnatal day 1 to day 14 (38.4-51.7/cell), then to postnatal month 1-2 (53.7-89.2/cell), reaching the maximum, then decreased to year 1-2 (83.7-80.4/cell) and the increase was stochastically significant $(\mathrm{P}<0.01)$. The results of visual grain counts on the number of mitochondria labeled with silver grains obtained from 10 mononucleate hepatocytes of each animal labeled with ${ }^{3} \mathrm{H}$-uridine demonstrating RNA synthesis in 10 aging groups at perinatal stages, prenatal embryo day 19, postnatal day 1,3, 9 and 14, month 1, 6 and year 1 and 2, were counted. The labeling indices in 
respective aging stages were calculated from the number of labeled mitochondria and the number of total mitochondria per cellular profile area, respectively. The results showed that the numbers of labeled mitochondria with ${ }^{3} \mathrm{H}$-uridine showing RNA synthesis increased from prenatal embryo day 19 (3.3/cell) to postnatal month 1 (9.2/cell), reaching the maximum, and then decreased to month $6(3.5 /$ cell $)$ and again increased to year $1(4.0 /$ cell $)$ and year 2 (4.3/cell), while the labeling indices increased from prenatal day $19(12.4 \%)$ to postnatal month $1(16.7 \%)$, reaching the maximum, then decreased to year $1(4.8 \%)$ and year $2(5.3 \%)$. Stochastical analysis revealed that the increases and decreases of the number of labeled mitochondria from the perinatal stage to the adult and senescent stage were significant in contrast that the increases and decreases of the labeling indices were not significant $(\mathrm{P}<0.01)$. As for the binucleate hepatocytes, on the other hand, because the appearances of binucleate hepatocytes were not so many in the embryonic stage, only several binucleate cells (5-8 at least) at respective stages when enough numbers of binucleate cells available from postnatal day 1 to year 2 were analyzed. The results of visual counts on the number of mitochondria labeled with silver grains obtained from several (5 to 8 ) binucleate hepatocytes labeled with ${ }^{3} \mathrm{H}$-uridine demonstrating RNA synthesis in 8 aging groups at perinatal stages, postnatal day $1,9,14$, and month 1, 2, 6, and year 1 and 2, were counted and the labeling indices in respective aging stages were calculated from the number of labeled mitochondria and the number of total mitochondria per cellular profile area calculated, respectively. The results showed that the number of labeled mitochondria increased from postnatal day 1 (2.3/cell) to day 9 (5.2/cell) and remained almost constant around 4-5, but the labeling indices increased from postnatal day $1(2.1 \%)$ to postnatal day $9(13.6 \%)$, remained almost constant around $13 \%$ (12.5-13.6\%) from postnatal day 9 to month 1, then decreased to month $2(6.1 \%)$ to month 6 (3.9\%), and slightly increased to year $1(6.3 \%)$ and $2(5.3 \%)$. The increases and decreases of the number of labeled mitochondria and the labeling indices in binucleate hepatocytes were stochastically not significant $(\mathrm{P}<0.01)$.

We also studied intracellular localization of mRNA in adult rat hepatocytes localizing over the peroxisomes by means of in situ hybridization technique (Usuda and Nagata 1992, 1995, Usuda et al. 1992). However, its relationship to the aging of animals was not yet studied.

\subsubsection{The protein synthesis in the liver}

As for the protein synthesis in the liver, we first studied the incorporations of ${ }^{3} \mathrm{H}$-leucine and ${ }^{3} \mathrm{H}$-tryptophane in mouse hepatocytes in connection to the binuclearity before and after feeding (Nagata 1967b, Nagata et al. 1967a, Ma et al. 1991). Then, we also studied mitochondrial protein synthesis in the liver later (Nagata 2006a, b, 2007b,c,e, 2009b, 2010c).

\subsubsection{The protein synthesis in hepatocyte nuclei}

We first studied the incorporations of amino-acids, ${ }^{3} \mathrm{H}$-leucine and ${ }^{3} \mathrm{H}$-tryptophane, in mouse mononucleate and binucleate hepatocytes before and after feeding (Nagata 1967b, Nagata et al. 1967a, Ma et al. 1991). The results showed that the incorporations of both amino acids were greater in binucleate hepatocytes than mononucleate. When ${ }^{3} \mathrm{H}$-leucine was injected into several groups of mice at various ages and the liver tissues were processed for LM and EM RAG, silver grains were observed over all cell types of the liver, i.e., hepatocytes (Fig. 9E), sinusoidal endothelial cells (Fig. 9F), ductal epithelial cells, Kupffer's cells, Ito's fat storing cells, fibroblasts and haematopoietic cells. In hepatocytes, number of silver grains in cytoplasm and karyoplasm increased from perinatal animals to postnatal 1 
month young adult animals and decreased with aging to senescence at 24 months. Number of silver grains observed over respective cell organelles, the Golgi apparatus, mitochondria and endoplasmic reticulum, changed with aging, reaching the maxima at 1 month but the ratio remained constant at each point. When ${ }^{3} \mathrm{H}$-proline was injected into mice at various ages from prenatal embryos to postnatal senescence, quantitative changes of collagen and protein synthesis in the livers were studied by electron microscopic radioautography (Ma and Nagata 2000, Nagata 2006a). The silver grains due to ${ }^{3} \mathrm{H}$-proline showing collagen synthesis were localized over the nuclei, cytoplasmic matrix, endoplasmic reticulum, the Golgi apparatus, mitochondria and peroxisomes of almost all the cells such as hepatocytes (Fig. 9F), sinusoidal endothelial cells, Kupffer's cells (Fig. 9G), Ito's fat-storing cells, ductal epithelial cells, fibroblasts and haematopoietic cells at various ages. The number of silver grains in the cell bodies and nuclei, cytoplasmic matrix, endoplasmic reticulum, mitochondria, the Golgi apparatus and peroxisomes of hepatocytes gradually increased from embryo, reaching the maxima at postnatal month 1 and 6, and decreased with aging until 24 months. The grain counts of the cell bodies reached the maximum at month 6 and the nuclei at month 2, while that of endoplasmic reticulum at month 6 and mitochondria at month 1 . The number of silver grains localized over the extracellular collagen fibrils and matrices was not so many in respective aging groups and did not show any remarkable changes with aging. From the results, it was concluded that ${ }^{3} \mathrm{H}$-proline was incorporated not only into collagen but also into the structural proteins of hepatocytes and increased and decreased due to aging under normal aging conditions.

\subsubsection{The protein synthesis in hepatocyte mitochondria}

When the aging mice at various ages from embryo to senescence were injected with $3 \mathrm{H}$ leucine, it was found that almost all the hepatocytes, from embryonic day 19, postnatal day 1 , $3,9,14$, to adult and senescent stages at postnatal month 1, 2, 6, 12 and 24, incorporated silver grains (Fig. 9E). The silver grains were also observed in binucleate hepatocytes at postnatal day 1, 3, 9, 14, month 1, 2, 6, 12 and 24 (Nagata 2007a,b,c,d, 2006a,b, 2007b,c,e). The localizations of silver grains observed over the mitochondria were mainly on the mitochondrial matrices but a few over their nuclei, cytoplasmic matrix, endoplasmic reticulum, ribosomes, Golgi apparatus and mitochondria (Nagata 2006a, b, 2007b, c, e). In the mitochondria the silver grains were localized over the mitochondrial membranes and cristae when observed by high power magnification. Preliminary quantitative analysis on the number of mitochondria in 20 mononucleate hepatocytes whose nuclei were intensely labeled with many silver grains (more than 10 per nucleus) and other 20 mononucleate hepatocytes whose nuclei were not so intensely labeled (number of silver grains less than 9) in each aging group revealed that there was no significant difference between the number of mitochondria, number of labeled mitochondria and the labeling indices in both types of hepatocytes $(\mathrm{P}<0.01)$.

On the other hand, the numbers of mitochondria, the numbers of labeled mitochondria and the labeling indices were calculated in 10 binucleate hepatocytes selected at random in each animal in respective aging stages, regardless whether their nuclei were very intensely labeled or not, except the prenatal stage at embryonic day 19, because no binucleate cell was found at this stage, resulted in no significant difference between them. Thus, the numbers of mitochondria, the numbers of labeled mitochondria and the labeling indices were calculated in 20 hepatocytes selected at random in each animal in respective aging stages regardless whether their nuclei were very intensely labeled or not. The results obtained from the total 
numbers of mitochondria in mononucleate hepatocytes showed an increase from the prenatal day $(34.5 /$ cell $)$ to postnatal days 1 (44.6/cell), 3 (45.8/cell), 9 (43.6/cell), 14 (48.5/cell), to postnatal months 1 (51.5/cell), 2 (52.3/cell), reaching the maximum at month 6 (60.7/cell), then decreased to years 1 (54.2/cell) and 2 (51.2/cell). The increase and decrease were stochastically significant $(\mathrm{P}<0.01)$. The results obtained from visual counting on the numbers of mitochondria labeled with silver grains from 20 mononucleate hepatocytes of each animal labeled with ${ }^{3} \mathrm{H}$-leucine demonstrating protein synthesis in 10 aging groups at perinatal stages, prenatal embryo day 19, postnatal day 1, 3, 9 and 14, month 1, 2, 6 and year 1 and 2, were counted. The labeling indices in respective aging stages were calculated from the numbers of labeled mitochondria and the numbers of total mitochondria per cell. The results showed that the numbers of labeled mitochondria with ${ }^{3} \mathrm{H}$-leucine showing protein synthesis increased from prenatal embryo day 19 (8.3/cell) to postnatal days 1 (9.6/cell), 3 (8.1/cell), 9 (8.9/cell), 14 (9.5/cell), and month 1 (11.2/cell), reaching the maximum, and then decreased to months 2 (9.1/cell), 6 (8.8/cell) to years 1 (6.7/cell) and $2(2.2 /$ cell), while the labeling indices increased from prenatal day $19(20.1 \%)$ to postnatal days $1(21.2 \%), 3$ $(21.6 \%), 9(22.2 \%), 14(23.1 \%)$, reaching the maximum, then decreased to month $1(21.7 \%), 2$ $(17.4 \%), 6(14.6 \%)$, and years $1(12.4 \%)$ and $2(4.4 \%)$. Stochastical analysis revealed that the increases and decreases of the numbers of labeled mitochondria as well as the labeling indices from the perinatal stage to the adult and senescent stages were significant $(\mathrm{P}<0.01)$.

The results obtained from the numbers of mitochondria in binucleate hepatocytes showed an increase from the postnatal days 1 (66.2/cell), to 3 (66.4/cell), 14 (81.8/cell), to postnatal months 1 (89.9/cell), 2 (95.1/cell), and 6 (102.1), reaching the maximum at month 12 (128.0/cell), then decreased to years 2 (93.9/cell). The increase and decrease were stochastically significant $(\mathrm{P}<0.01)$. The results obtained from visual counting on the numbers of mitochondria labeled with silver grains from 10 binucleate hepatocytes of each animal labeled with ${ }^{3} \mathrm{H}$-leucine demonstrating protein synthesis in 10 aging groups at postnatal day 1,3 , and 14, month 1, 2, 6 and year 1 and 2, were counted. The labeling indices in respective aging stages were calculated from the numbers of labeled mitochondria and the numbers of total mitochondria per cell which showed that the numbers of labeled mitochondria with ${ }^{3} \mathrm{H}$-leucine showing protein synthesis increased from postnatal day 1 (7.3/cell) to day 3 (6.8/cell), 14 (10.2/cell), and month 1 (15.0/cell), 2 (15.9/cell), reaching the maximum at month 6 (19.6/cell), then decreased to year $1(8.3 /$ cell $)$ and $2(5.1 /$ cell), while the labeling indices increased from postnatal day $1(11.8 \%)$ to $3(10.2 \%), 14(12.5 \%)$, month $1(18.3 \%)$ and $2(18.7 \%)$, reaching the maximum at month $6(19.2 \%)$, then decreased to year $1(6.4 \%)$ and 2 (5.5\%). Stochastical analysis revealed that the increases and decreases of the numbers of labeled mitochondria as well as the labeling indices from the newborn stage to the adult and senescent stages were significant $(\mathrm{P}<0.01)$. The silver grains due to ${ }^{3} \mathrm{H}$-leucine were also observed in sinusoidal endothelial cells (Fig. 8F), Kupfer's cells, Ito's fat-storing cells, ductal epithelial cells, fibroblasts and hematopoietic cells at various ages.

When ${ }^{3} \mathrm{H}$-prolin was injected into aging mice at various ages, silver grains were localized over the nuclei, cytoplasmic matrix, endoplasmic reticulum, the Golgi apparatus, mitochondria and peroxisomes of all the cell such as hepatocytes (Fig. 9G), sinusoidal endothelial cells, Kupfer's cells (Fig. 9H), Ito's fat-storing cells, ductal epithelial cells, fibroblasts and hematopoietic cells at various ages. The number of silver grains in hepatocytes gradually increased from perinatal stage to postnatal month 1 to 6 due to aging, reaching the maximum and decreased to momth 24 . The number of silver grains localized the extracellular collage fibrils and matrices was not so great in respective aging groups and 
did not show any remarkable changes with aging. From the results, it was concluded that ${ }^{3} \mathrm{H}$-prolin was incorporated not only into collagen but also into the structural proteins of hepatocytes under normal aging conditions (Ma and Nagata 2000).

\subsubsection{The glucide synthesis in the liver}

We first studied ${ }^{3} \mathrm{H}$-glucose incorporation into glycogen in the livers of adult mice, in connection to soluble compounds (Nagata and Murata 1977, Nagata et al. 1977a,d). Soluble ${ }^{3} \mathrm{H}$-glucose, which was demonstrated by cryo-fixation $\left(\right.$ at $\left.-196^{\circ} \mathrm{C}\right)$ in combination with drymounting radioautography, was localized over the nuclei, nucleoli, all the cell organelles and cytoplasmic ground substance of all the hepatocytes diffusely. On the other hand, by conventional chemical fixation and wet-mounting radioautography, silver grains were localized only over glycogen granules, endoplasmic reticulum and Golgi apparatus showing glycogen synthesis. However, the relationship of glycogen synthesis to aging has not yet been fully clarified.

\subsubsection{The lipids synthesis in the liver}

We observed lipids synthesis in the liver using ${ }^{3} \mathrm{H}$-glycerol in connection to soluble compounds (Nagata 1994a,d, Nagata and Murata 1977a, Nagata et al. 1977a,d). When adult mice were injected with ${ }^{3} \mathrm{H}$-glycerol and the livers were taken out, cryo-fixed in liquid nitrogen at $-196^{\circ} \mathrm{C}$, then freeze-substituted, embedded in epoxy resin, dry-sectioned, and prepared for dry-mounting radioautography, many silver grains appeared over the nuclei and cytoplasm of hepatocytes diffusely. However, when the same liver tissues were fixed chemically in buffered glutaraldehyde and osmium tetroxide at $4^{\circ} \mathrm{C}$, dehydrated, embedded, wet-sectioned and radioautographed by conventional wet-mounting procedures, very few silver grains were observed only over the endoplasmic reticulum and the lipid droplets, which demonstrated insoluble macromolecular lipid synthesis accumulating into the lipid droplets. However, the aging change of the lipid synthesis in the liver has not yet been fully clarified.

\subsection{Macromolecular synthesis in the pancreas}

The pancreas is a large gland, next to the liver in men and animals, among the digestive glands connected to the intestines. It consists of exocrine and endocrine portions and takes the shape of a compound acinous gland. The exocrine portion is composed of ductal epithelial cells, centro-acinar cells, acinar cells and connective tissue cells, while the endocrine portion, the islet of Langerhans, is composed of 3 types of endocrine cells, A, B, C cells and connective tissue cells. Intracellular transport of secretory proteins in the pancreatic exocrine cells were formerly studied by Jamieson and Palade (1967) by EMRAG. We studied the macromolecular synthesis of the aging mouse pancreas at various ages.

\subsubsection{The DNA synthesis in the pancreas}

We first studied the DNA synthesis of mouse pancreas by LM and EMRAG using ${ }^{3} \mathrm{H}-$ thymidine (Nagata and Usuda 1984, 1985, 1986, Nagata et al. 1986). Light and electron microscopic radioautograms of the pancreas revealed that the nuclei of pancreatic acinar cells (Fig. 11A), centro-acinar cells (Fig. 11B), ductal epithelial cells, and endocrine cells were labeled with ${ }^{3} \mathrm{H}$-thymidine. The labeling indices of these cells in 5 groups of litter mate mice, fetal day 15, postnatal day 1, 20,60 (2 months) and 730 (2 years) were analyzed. 

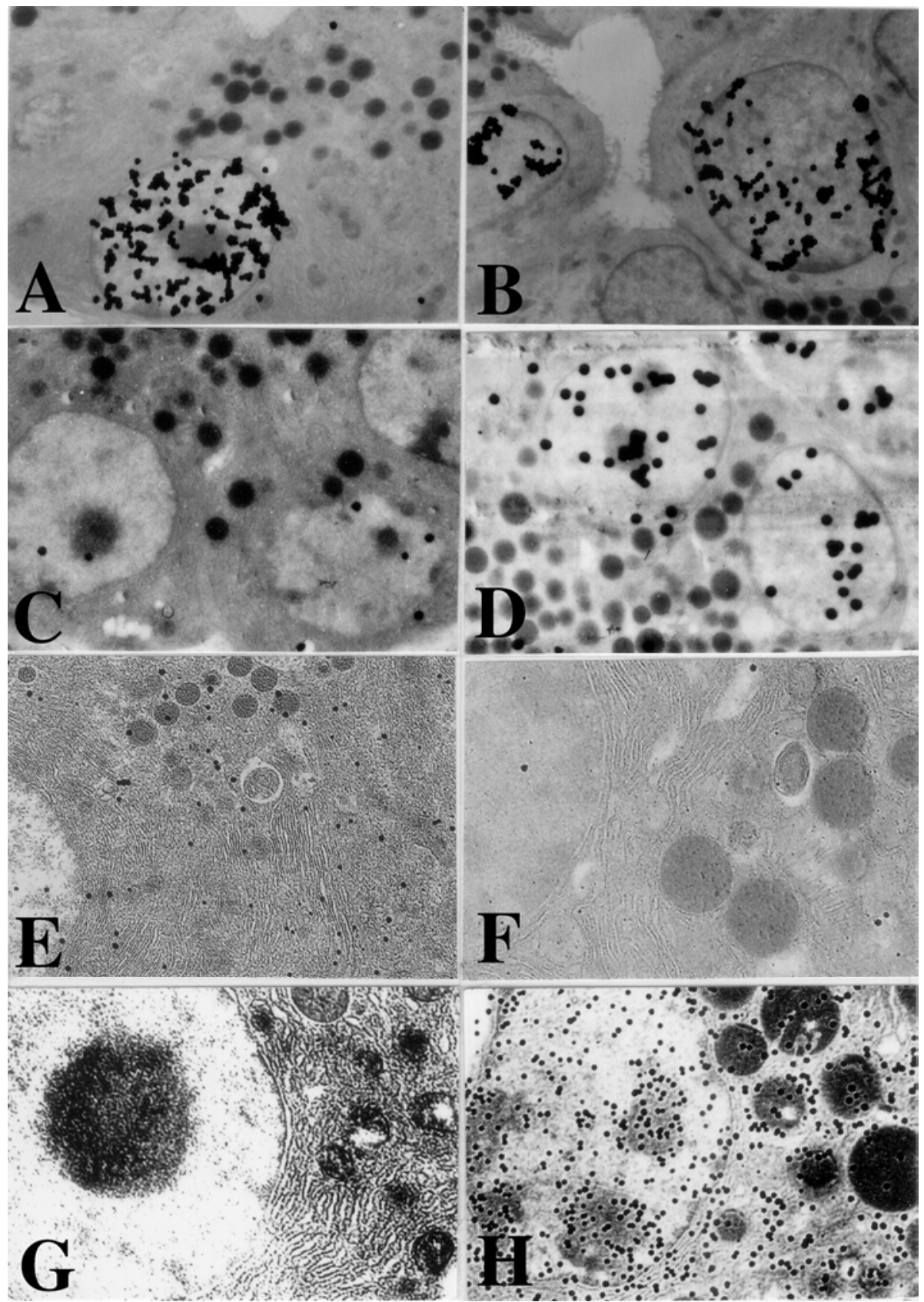

Fig. 11. EM RAG of the pancreas. From Nagata, T.: Radioautographology, General and Special. In, Prog. Histochem. Cytochem. Vol. 37, No. 2, p. 140, 2002, Urban \& Fischer, Jena, Germany 
Fig. 11A. EM RAG of 2 pancreatic acinar cells of a 14 day old mouse labeled with ${ }^{3} \mathrm{H}-$ thymidine, showing DNA synthesis. $x 10,000$.

Fig. 11B. EM RAG of 2 centro-acinar cells of a 14 day old mouse labeled with ${ }^{3} \mathrm{H}$-thymidine, showing DNA synthesis. $x 10,000$.

Fig. 11C. EM RAG of 3 pancreatic acinar cells of a 1 day old mouse labeled with ${ }^{3} \mathrm{H}$-uridine, showing RNA synthesis. $x 10,000$.

Fig. 11D. EM RAG of 3 pancreatic acinar cells of a 14 day old mouse labeled with ${ }^{3} \mathrm{H}$-uridine, showing RNA synthesis. $x 10,000$.

Fig. 11E. EM RAG of a pancreatic acinar cell of a 30 day old mouse labeled with ${ }^{3} \mathrm{H}-$ leucine, showing protein synthesis. $x 10,000$.

Fig. 11F. EM RAG of a pancreatic acinar cell of a 12 month old mouse labeled with ${ }^{3} \mathrm{H}-$ leucine, showing protein synthesis. $x 10,000$.

Fig. 11G. EM RAG of a pancreatic acinar cell of a 1 day old mouse labeled with ${ }^{3} \mathrm{H}-$ glucosamine, showing glucide synthesis. $x 10,000$.

Fig. 11H. EM RAG of a pancreatic acinar cell of a 14 day old mouse labeled with ${ }^{3} \mathrm{H}-$ glucosamine, showing glucide synthesis. $x 10,000$.

The labeling indices of these cells reached the maxima at day 1 after birth and decreased gradually to 2 years (Fig. 12). The maximum in the acinar cells proceeded to the ductal and centro-acinar cells, suggesting that the acinar cells completed their development earlier than the ductal and centro-acinar cells (Nagata et al. 1986).

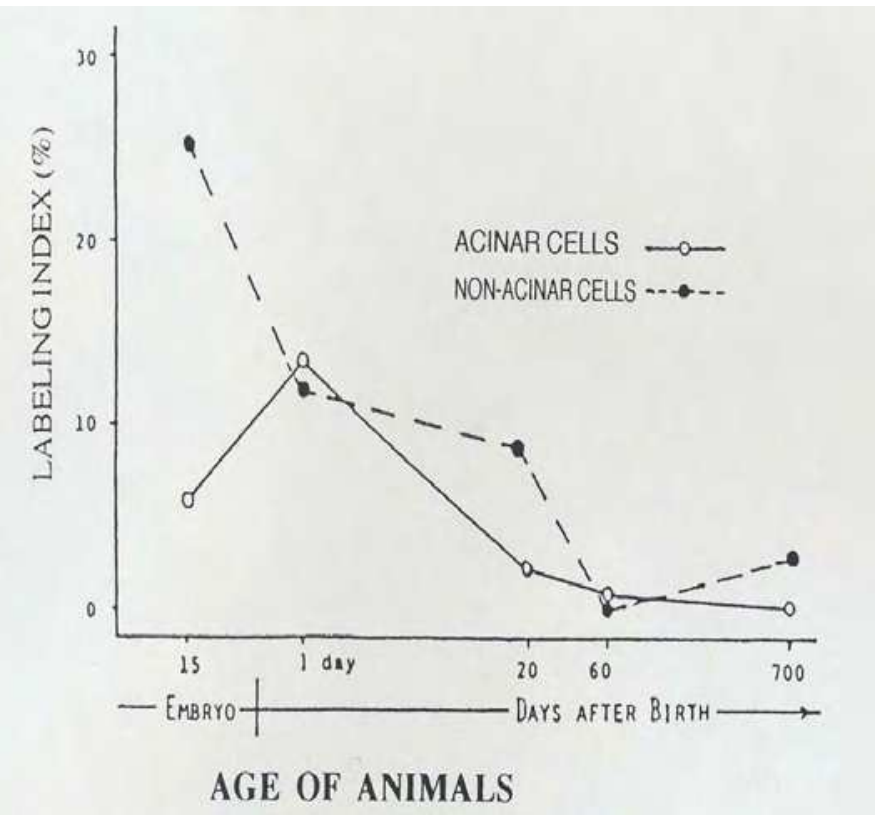

Fig. 12. Transitional curves of the labeling indices of respective cell types of the pancreas of aging mice labeled with ${ }^{3} \mathrm{H}$-thymidine, showing DNA synthesis. Mean \pm Standard Deviation. From Nagata, T.: Radioautographology, General and Special. In, Prog. Histochem. Cytochem. Vol. 37, No. 2, p. 142, 2002, Urban \& Fischer, Jena, Germany 


\subsubsection{The RNA synthesis in the pancreas}

On the other hand, LM and EMRAG of pancreas of mouse injected with ${ }^{3} \mathrm{H}$-uridine demonstrated its incorporation into exocrine and then in endocrine cells, and more in pancreatic acinar cells (Figs. 11C,D) than in ductal or centro-acinar cells (Nagata and Usuda 1986a,b, Nagata et al. 1986). Among the acinar cells, the number of silver grains increased after birth to day 14 and then decreased with aging. Quantification of silver grains in the nucleoli, chromatin, and cell body were carried out by X-ray microanalysis (Nagata 1991, 1993, 2004, Nagata and Usuda 1985), which verified the results obtained by visual grain counting. In EMRAG obtained from the pancreas of fetal day 19 embryos, newborn day 1 and newborn day 14 mice labeled with ${ }^{3} \mathrm{H}$-uridine, demonstrating RNA synthesis, the number of silver grains in the nucleoli, nuclear chromatin and cytoplasm increased (Nagata 1985, 1991, 1993a,b, 2004, Nagata and Usuda 1985, 1986). In order to quantify the silver contents of grains observed over the nucleoli, nuclei and cytoplasm, X-ray spectra were recorded by energy dispersive X-ray microanalysis (JEM-4000EX TN5400), demonstrating Ag-Ka peaks at higher energies. Thus, $\mathrm{P} / \mathrm{B}$ ratios expressing relative silver contents were determined and compared between the two age groups. The results obtained by X-ray microanalysis in different cell compartments at postnatal day 1 and day 14 and he results obtained by visual grain counting in different cell compartments in day 1 day and day 14 animals were compared. The number of silver grains was calculated to express the counts per unit area to be compared with the XMA counts. These two results, the silver content analyzed by $\mathrm{X}$-ray microanalysis and the results obtaining from visual grain counting were in good accordance with each other.

\subsubsection{The protein synthesis in the pancreas}

As for the protein synthesis in the pancreas, ${ }^{3} \mathrm{H}$-leucine incorporation into endoplasmic reticulum, Golgi apparatus and to secretory granules of pancreatic acinar cells was first demonstrated by Jamieson and Palade (1967). We first studied ${ }^{3} \mathrm{H}$-glycine incorporation into these cell organelles of mouse pancreatic acinar cells in connection with soluble compounds by EM RAG (Nagata 2000c, 2007a). It was demonstrated that soluble ${ }^{3} \mathrm{H}$-glycine distributed not only in these cell organelles but also in the karyoplasm and cytoplasm diffusely. Then, the quantitative aspects of protein synthesis with regards the aging from fetal day 19, to postnatal day 1, 3, 7, 14 and 1, 2, 6 and 12 months were also clarified (Nagata and Usuda 1993a, Nagata 2000c). The results showed an increase of silver grain counts labeled with ${ }^{3} \mathrm{H}-$ leucine after birth, reaching a peak from postnatal 2 weeks to 1 month (Fig. 10E), and decreasing from 2 months to 1 year (Fig. 11F).

On the other hand, we also studied ${ }^{3} \mathrm{H}$-leucine incorporations into the pancreatic acinar cells of both normal adult rats and experimentally pancreatitis induced rats with either ethionine or alcohol (Yoshizawa et al. 1974, 1977). The results showed that the incorporations as indicated silver grain counts in the pancreatitis rats were less than normal control rats. However, its relation to the aging was not yet studied.

\subsubsection{The glucide synthesis in the pancreas}

Concerning the glucide synthesis of the pancreas, we first studied the incorporation of ${ }^{3} \mathrm{H}$ glucose into the pancreatic acinar cells of mouse in connection with soluble compounds by 
EM RAG (Nagata et al. 1977a). It was demonstrated that soluble ${ }^{3} \mathrm{H}$-glucose distributed not only in such cell organelles as endoplasmic reticulum, Golgi apparatus, mitochondria but also in the karyoplasm and cytoplasm diffusely. Then, the incorporation of ${ }^{3} \mathrm{H}$-glucosamine into the pancreases of aging mice at various ages was studied by LM and EM RAG (Nagata et al. 1992). When perinatal baby mice received ${ }^{3} \mathrm{H}$-glucosamine injections and the pancreatic tissues were radioautographed, silver grains were observed over exocrine and endocrine pancreatic cells. However, the number of silver grains was not so many (Fig. $11 G)$. When juvenile mice at the age of 14 days after birth were examined, many silver grains appeared over the exocrine pancreatic acinar cells (Fig. $11 \mathrm{H}$ ). Less silver grains were observed over endocrine pancreatic cells and ductal epithelial cells. The grains in the exocrine pancreatic acinar cells were localized over the nucleus, endoplasmic reticulum, Golgi apparatus and secretory granules, demonstrating glycoprotein synthesis. Adult mice at the ages of postnatal 1 month, 6 month or senile mice at the ages of 12 months or 24 months showed very few silver grains on radioautograms. Thus, the glucide synthesis in the pancreatic acinar cells of mice revealed quantitative changes, increase and decrease of $3 \mathrm{H}-$ glucosamine incorporation with aging (Nagata 1994a,b,c,d,e, Nagata et al. 1992).

\subsubsection{The lipids synthesis in the pancreas}

In order to demonstrate the lipids synthesis in the pancreas, several litters of ddY mice aged fetal day 19, postnatal day $1,3,7,14$, and $1,2,6$ up to 12 months, were injected with ${ }^{3} \mathrm{H}$ glycerol and the pancreas tissues were prepared for LM and EM RAG. The silver grains were observed in both exocrine and endocrine cells of respective ages (Nagata 1995a,b, Nagata et al. 1988b, 1990). In perinatal animals from fetal day 19 to postnatal 1, 3, and 7 days, cell organelles were not well developed in exocrine and endocrine cells and number of silver grains was very few. In 14 day old juvenile animals, cell organelles such as endoplasmic reticulum, Golgi apparatus, mitochondria and secretory granules were well developed and many silver grains were observed over these organelles and nuclei in both exocrine and endocrine cells. The number of silver grains was more in exocrine cells than endocrine cells. In 1, 2, 6 month old adult animals, number of silver grains remained constant. In 12 month old senescent animals, silver grains were fewer than younger animals. It was demonstrated that the number of silver grains expressed the quantity of lipids synthesis, which increased from perinatal atages to adult and senescent stages and finally decreased to senescence.

\section{Macromolecular synthesis in the respiratory system}

The respiratory system consists of 2 parts, the air-conducting portion and the respiratory portion. The former are the nose, the pharynx, the larynx and the trachea, while the latter the lung. We studied the macromolecular synthesis in the pulmonary tissues as well as the tracheal tissues at various ages from embryo to postnatal 2 years.

\subsection{The DNA synthesis in the respiratory system}

Among the air-conducting portion and the respiratory portion we studied the macromolecular synthesis in the tracheal tissues as well as the pulmonary tissues at various ages from embryo to postnatal 2 years (Sun et al. 1994, 1995a,b, 1997a,b, Nagata 2000d). 


\subsubsection{The DNA synthesis in the trachea}

The tracheas of mammals are composed of ciliated pseudostratified columnar epithelia, connective tissues, smooth muscles and hyalin cartilages surrounding the epithelia. The changes of DNA synthesis of tracheal cells in aging mice were studied by LM and EMRAG (Sun et al. 1997a, Nagata 2000d). The tracheae of 8 groups of mice from fetal day 18 to 2 years after birth were examined. The results demonstrated that the DNA syntheses and morphology of tracheal cells in the mouse tracheae changed due to aging. The radioautograms revealed that the DNA synthesis in the nuclei of ciliated cells was observed only in the fetal animals (Fig. 13A). However, the DNA synthesis in nonciliated cells and basal cells was observed in both prenatal and postnatal animals (Fig. 13B). The labeling indices of respective cell types were analyzed (Sun et al. 1997a). As the results, the labeling indices of the epithelial cells showed their maxima on fetal day 18, then fell down from postnatal day 3 to 2 years (Fig. 14A). The ciliated cell could not synthesize DNA and proliferate in the postnatal stage. They are supposed to be derived by the division and transformation of the basal cells. On the other hand, the DNA synthesis of chondrocytes was the highest on embryonic day 18, and rapidly declined on postnatal day 3 (Fig. 13C). The chondrocytes lost the ability of synthesizing DNA at 2 months after birth (Fig. 14B). The labeling indices of other cells (including fibroblasts, smooth muscle and glandular cells) were the highest on fetal day 18 and fell down markedly on the third day after birth and decreased progressively due to aging (Fig. 14C).

\subsubsection{The DNA synthesis in the lung}

We studied the pulmonary tissues at various ages from embryo to postnatal 2 years of mice (Sun et al. 1995a,b). The pulmonary tissues obtained from ddY strain mice at various ages from embryo day 19 to adult postnatal day 30 and to year 2 consisted of several types of cells, i.e., the type I epithelial cells or the small alveolar epithelial cells, type II epithelial cells or large alveolar epithelial cells, interstitial cells and endothelial cells, which incorporated macromolecular precursors respectively (Figs. 13E, F, G, H).

\subsubsection{The DNA synthesis in the pulmonary cells}

The pulmonary tissues obtained from ddY strain mice at embryonic to early postnatal stages consisted of undifferentiated cells (Fig. 13E). However, they differentiated into several types of cells due to aging, the type I epithelial cells or the small alveolar epithelial cells (Fig. 13E), the type II epithelial cells or the large alveolar epithelial cells (Fig. 13F), the interstitial cells (Fig. 13G), the endothelial cells (Fig. 13H) and alveolar phagocytes or dust cells as we had formerly observed (Sun et al. 1995a,b). At embryonic day 16 and 18, the fetal lung tissues appeared as glandular organizations consisting of many alveoli bordering undifferentiated cuboidal cells and no squamous epithelial cells were seen (Figs. 13E, 13G). Mitotic figures were frequently observed in cuboidal epithelial cells. After birth, the structure of the alveoli was characterized by further development of the alveolar-capillary networks from postnatal day 1 to 3 and 7 (Fig. 13H). During the development, the cellular composition of the alveolar epithelium resembled that of the adult lung, with a mixed population of the type I and type II epithelial cells. Up to 1 and 2 weeks after birth, the lung tissues showed complete alveolar structure and single capillary system almost the same as the adult after 1 month (Fig. 13F) to 2 to 6 months, and further to senescent stage over 12 months to 22 months. On electron microscopic radioautograms of the pulmonary tissues labeled with ${ }^{3} \mathrm{H}$-thymidine, silver grains were observed over the nuclei of some pulmonary cells corresponding to the DNA synthesis in S-phase as observed by light microscopic radioautograpy (Sun et al. 1995a,b, 1997a). 


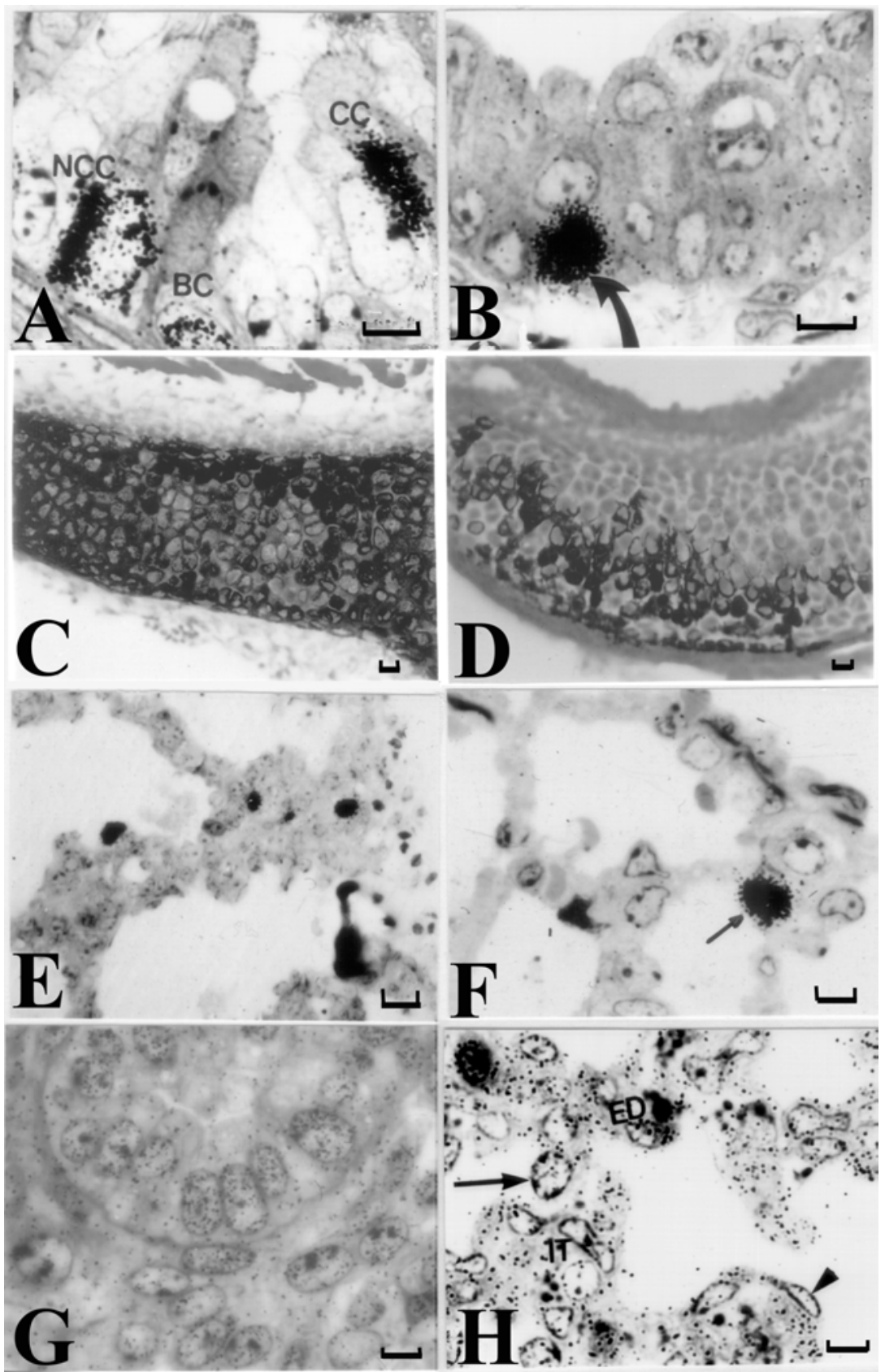

Fig. 13. LM RAG of the respiratory organs. From Nagata, T.: Special Cytochemistry in Cell Biology, In, Internat. Rev. Cytol. Vol. 211, No. 1, p. 102, 2001, Academic Press, San Diego, USA, London, UK. 
Fig. 13A. LM RAG of the tracheal epithelial cells of a prenatal day 18 mouse embryo labeled with ${ }^{3} \mathrm{H}$-thymidine, showing DNA synthesis. $x 1,125$.

Fig. 13B. LM RAG of the tracheal epithelial cells of a postnatal 1 month old mouse labeled with ${ }^{3} \mathrm{H}$-thymidine, showing DNA synthesis. $x 1,125$.

Fig. 13C. LM RAG of the tracheal cartilage cells of a prenatal day 19 mouse embryo labeled with $35 \mathrm{SO}_{4}$ showing mucosubstance synthesis. $x 400$.

Fig. 13D. LM RAG of the tracheal cartilage cells of a postnatal day 3 mouse labeled with ${ }^{35} \mathrm{SO}_{4}$ showing mucosubstance synthesis. $x 400$.

Fig. 13E. LM RAG of the lung of a 1 day old mouse labeled with ${ }^{3} \mathrm{H}$-thymidine, showing DNA synthesis. $x 750$.

Fig. 13F. LM RAG of the lung of a 1 month old mouse labeled with ${ }^{3} \mathrm{H}$-thymidine, showing DNA synthesis. $x 750$.

Fig. 13G. LM RAG of the lung of a prenatal day 16 mouse embryo labeled with ${ }^{3} \mathrm{H}$-uridine, showing RNA synthesis. $x 750$.

Fig. $13 \mathrm{H}$. LM RAG of the lung of a 7 day old mouse labeled with ${ }^{3} \mathrm{H}-\mathrm{leucine}$, showing protein synthesis. $x 750$.

The DNA synthetic activity of respective pulmonary cells as expressed by labeling indices demonstrated increases from perinatal stage to developmental stage and decreased due to aging. We also studied inhalation of ${ }^{3} \mathrm{H}$-thymidine in air by means of a nebulizer into the lungs of 1 week old young mice as experimental studies and observed by LM and EM RAG (Duan et al. 1994). After $10 \mathrm{~min}$. inhalation, the lung tissues were taken out and processed by either rapid freezing and freeze-substitution for dry-mounting radioautography or conventional chemical fixation for wet-mounting radioautography. By wet-mounting RAG silver grains were observed in the nuclei of a few alveolar type 2 cells and interstitial cells demonstrating DNA synthesis. By dry-mounting RAG, numerous silver grains were located diffusely over all the epithelial cells and interstitial cells demonstrating soluble compounds. The results showed that ${ }^{3} \mathrm{H}$-thymidine inhaled into the lung distributed over all the pulmonary cells but only some of the alveolar type 2 cells and interstitial cells did synthesize DNA.

On the other hand, we studied the aging changes of DNA synthesis in the lungs of salamanders, Hynobius nebolosus, from larvae at 2 month after fertilization, juvenile at 1 month, adults at 10 and 12 months after metamorphosis, and finally to senescence at 5 years by LM RAG after ${ }^{3} \mathrm{H}$-thymidine injections (Matsumura et at. 1994). The results showed that the labeling indices of in the ciliated cells and mucous cells in the superficial layer of young animals were higher than those of the basal cells and they decreased in adults, demonstrating aging changes in salamanders.

\subsubsection{The DNA synthesis in mitochondria of mouse pulmonary cells}

On electron microscopic radioautograms of the pulmonary tissues labeled with ${ }^{3} \mathrm{H}$ thymidine, silver grains were observed over not only the nuclei of some pulmonary cells corresponding to the DNA synthesis in S-phase as observed by LM radioautograpy (Sun et al. 1995a,b) but also over the mitochondria by EMRAG (Sun et al. 1995b). Some mitochondria in both S-phase cells and interphase cells which did not show any silver grains over their nuclei were labeled with silver grains showing intramitochondrial DNA 
synthesis. The intramitochondrial DNA synthesis was observed in all cell types, the type I epithelial cells, the type II epithelial cells (Figs. 13F,G), the interstitial cells (Fig. 13F) and the endothelial cells. Because enough numbers of electron photographs (more than 5) were not obtained from all the cell types in respective aging groups, only some cell types and some aging groups when enough numbers of electron photographs were available were used for quantitative analysis. The numbers of mitochondria per cell profile area, the numbers of labeled mitochondria per cell and the labeling indices of the type I epithelial cells in only a few aging groups were observed and counted. The labeling indices in respective aging stages were calculated from the number of labeled mitochondria and the number of total mitochondria per cellular profile area which were calculated, respectively. These results demonstrated that the labeling indices in these cell types decreased from prenatal stages at embryo day 16 to day 18 (20-25\%), and further decreased to postnatal days up to senescent stages due to aging (Fig. 15).

\subsection{The RNA synthesis in the respiratory system}

We studied the lungs of aging mice among the respiratory organs after administration of ${ }^{3} \mathrm{H}$-uridine at various ages from prenatal embryonic day 16 to postnatal senescent month 22 as observed by LM and EM RAG (Fig. 13H).

\subsubsection{RNA synthesis of mouse pulmonary cells}

When the lung tissues of mice were labeled with ${ }^{3} \mathrm{H}$-uridine, RNA synthesis was observed in all cells of the lungs at various ages by RAG (Sun 1995, Sun et al. 1997b, Nagata 2002). Observing the light microscopic radioautograms labeled with ${ }^{3} \mathrm{H}$-uridine, the silver grains were found over both the karyoplasm and cytoplasm of almost all the cells not only at the perinatal stages from embryo day 16, 18, to postnatal day 1,3, 7, 14, but also at the adult and senescent stages from postnatal month 1 to 2, 6, 12 and 22. The number of silver grains, by electron micrography, changed with aging. The grain counts in type I epithelial cells increased from the 1st day after birth and reached a peak at 1 week and decreased gradually to month 22, while the counts in type II epithelial cells (Fig. 13H), interstitial cells and endothelial cells increased from embryo day 16 and reached peaks at 1 week after birth, then decreased to senescence.

\subsubsection{The RNA synthesis of mitochondria in pulmonary cells}

By electron microscopic radioautography, silver grains were observed in most pulmonary cells in respective aging groups localizing not only over euchromatin and nucleoli in the nuclei but also over many cell organelles such as endoplasmic reticulum, ribosomes, and mitochondria as well as cytoplasmic matrices from perinatal stage at embryonic day 16, 18 , to postnatal day $1,3,7,14$, to adult and senescent stages at postnatal month $1,2,6,12$ and 22 (Sun 1995, Sun et al. 1997b, Nagata 2002). The localizations of silver grains over the mitochondria were mainly on the mitochondrial matrices but a few over the mitochondrial membranes and cristae when observed by high power magnification. However, quantitative analyses on the number of mitochondria, the number of labeled mitochondria and the labeling index were not performed because enough number of EM RAG was not obtained. 


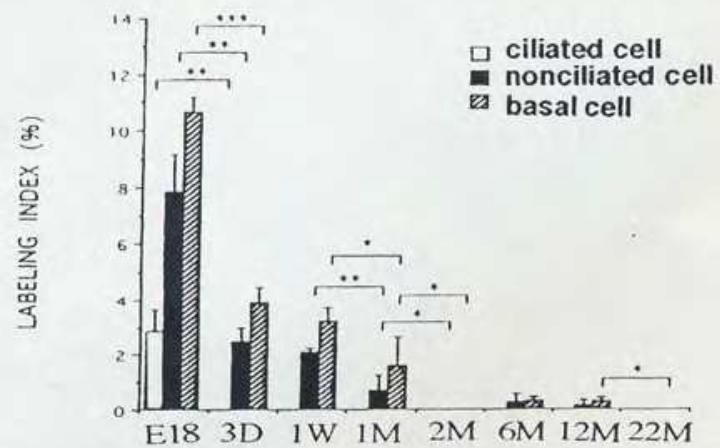

A

AGE OF ANIMALS

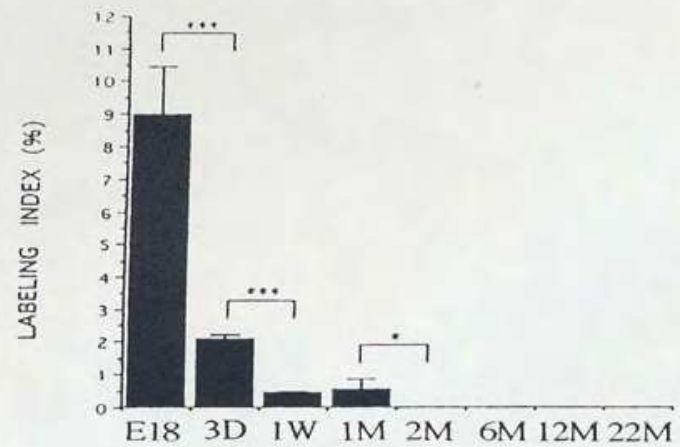

B

AGE OF ANIMALS

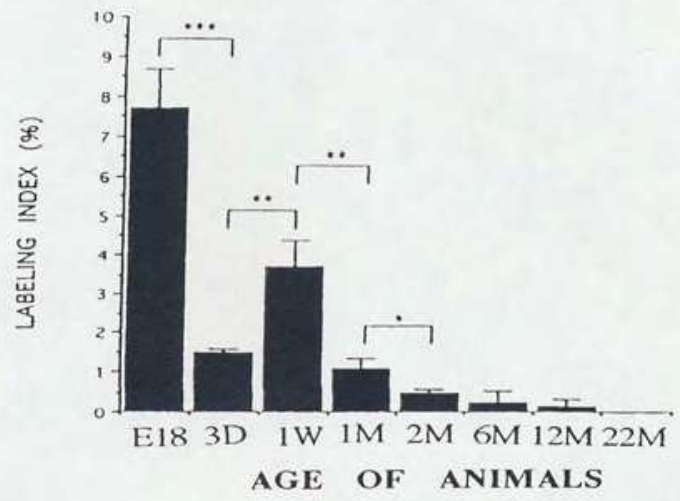

Fig. 14. Histogram showing aging changes of average labeling indices in respective cell types of the trachea of aging mice labeled with ${ }^{3} \mathrm{H}$-thymidine. Mean \pm Standard Deviation. From Nagata, T.: Radioautographology, General and Special. In, Prog. Histochem. Cytochem. Vol. 37, No. 2, p. 148, 2002, Urban \& Fischer, Jena, Germany Fig. 14A. Epithelial cells.

Fig. 14B. Chondrocytes in the cartilage.

Fig. 14C. Other cells. 


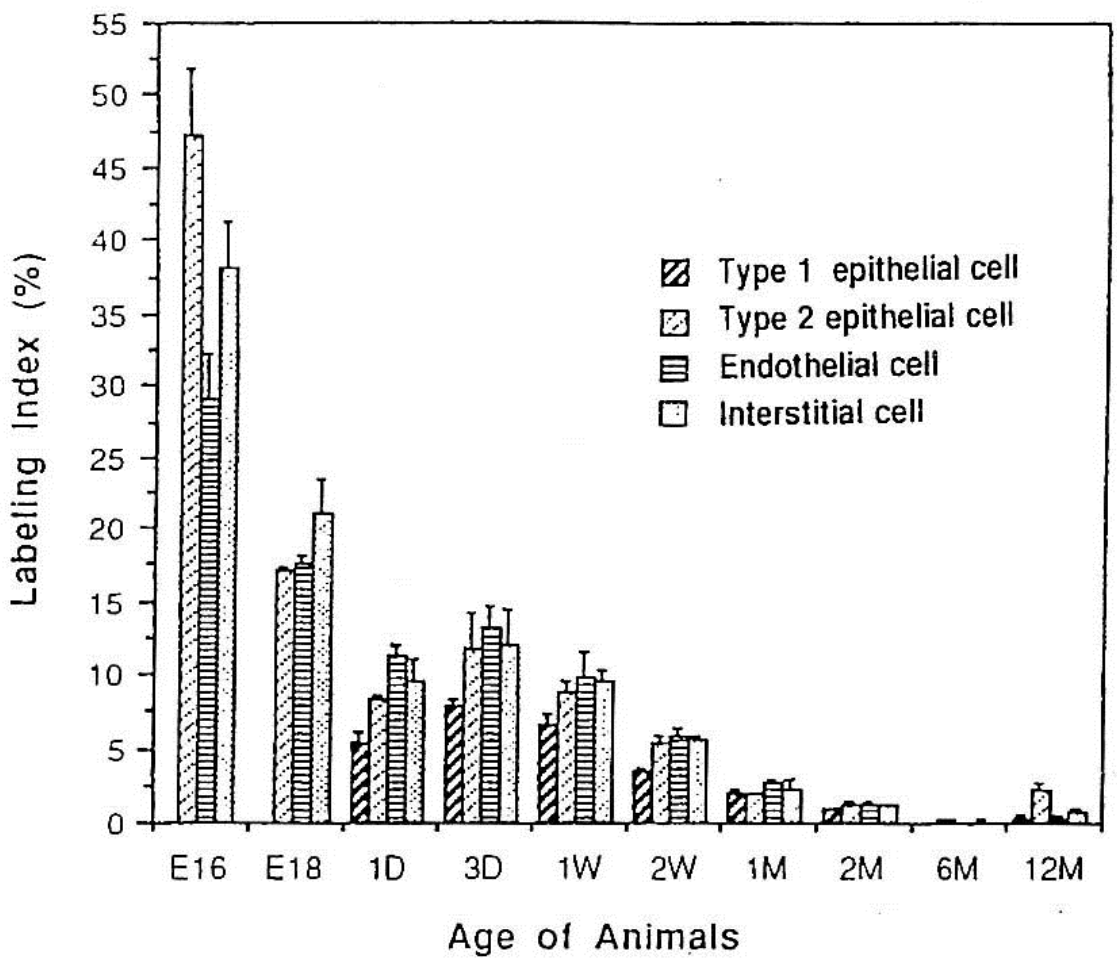

Fig. 15. Histogram showing aging changes of average labeling indices in respective cell types of the tracheal epithelial cells of aging mice labeled with ${ }^{3} \mathrm{H}$-thymidine. Mean \pm Standard Deviation. From Nagata, T.: Radioautographology, General and Special. In, Prog. Histochem. Cytochem. Vol. 37, No. 2, p. 149, 2002, Urban \& Fischer, Jena, Germany

\subsection{The protein synthesis in the respiratory system}

We studied the protein synthesis only in the lungs of aging mice at various ages among the respiratory organs including the respiratory tract.

\subsubsection{Protein synthesis of aging mouse pulmonary cells}

When the lung tissues of mice at various ages were labeled with ${ }^{3} \mathrm{H}$-leucine, protein synthesis was observed in all types of cells, type I and type II epithelial cells, interstitial cells and endothelial cells, of the lungs at various ages from embryo to senescence (Sun et al. 1997b). Observing the light microscopic radioautograms, the silver grains were detected over both the karyoplasm and cytoplasm of almost all the cells not only at the perinatal stages from embryo day 16, 18, to postnatal day 1 to 14 (Fig. 13I), but also at the adult and senescent stages from postnatal month 1 to 2, 6, 12 and 22. The number of silver grains, by light microscopic radioautography, changed with aging. The grain counts in type I epithelial cells were the highest on postnatal day 1 , decreased on day 3 and increased again at 1 week, 
then decreased gradually to month 22, while the counts in type II epithelial cells, interstitial cells and endothelial cells reached the highest levels on fetal day 16, declined progressively with aging from fetal day 18 to postnatal day 3, then increased again from postnatal to day 7 , reached peaks at 1 week (day 7) after birth, then decreased to senescence. However, grain counting on cell organelles by electron microscopy was not performed because enough numbers of EM RAG were not obtained at that time.

\subsection{The glucide synthesis in the respiratory system}

The incorporation of $35 \mathrm{SO}_{4}$ in the trachea of aging mice was studied among the respiratory organs (Nagata 2000d). As the results, silver grains indicating the incorporations of radiosulfate were found over the cartilage matrices and the cartilage capsules in the hyaline cartilages of the tracheae of fetal (Fig. 13C) and postnatal newborn mice (Fig. 13D). The grain density as analyzed by grain densitometry was the maximum at the fetal day 19 (1200 grains per unit area). The grain density then decreased from the fetal day 19 to the postnatal day 1, 3, 7 (600/area), 14 (200/area) and reached 0 on day 30, and no silver grain was found in the animals aged from 1 to 12 months. The silver grains in the perinatal animals aged at postnatal day 1 and 3, disappearred from the internal layer to the external layer of the cartilage and from the interterritorial matrix to the territorial matrix and the cartilage capsule. In the juvenile animals aged at postnatal day 9 and 14, intense incorporations were observed disseminatedly over several groups of cartilage capsules in the external layer. The results indicated that the glycoproteins constituting the cartilage matrix were synthesized from prenatal to postnatal day 30 . To the contrary, no incorporation of silver grains was observed in the aging animals from postnatal 1 to 12 months by both LM and EM RAG. These results demonstrated the aging changes of glycoprotein synthesis in the cartilage matrix of mice at various ages during development and aging.

\section{References}

Chen, S., Gao, F., Kotani, A., Nagata, T.: Age-related changes of male mouse submandibular gland: A morphometric and radioautographic study. Cell. Mol. Biol. 41, 117-124, 1995.

Clermont Y.: The contractime elements in the limiting membrane of the seminiferous tubules of rats. Exp. Cell Res. 15, 438-342, 1958.

Clermont, Y.: Renewal of spermatogonia in man. Amer. J. Anat. 112, 35-51, 1963.

Cui, H.: Light microscopic radioautographic study on DNA synthesis of nerve cells in the cerebella of aging mice. Cell. Mol. Biol. 41, 1139-1154, 1995.

Cui, H., Gao, F., Nagata, T.: Light microscopic radioautographic study on protein synthesis in perinatal mice corneas. Acta Histochem. Cytochem. 33, 31-37, 2000.

Duan, H., Gao, F., Li, S., Hayashi, K., Nagata, T.: Aging changes and fine structure and DNA synthesis of esophageal epithelium in neonatal, adult and old mice. J. Clin. Electron Microsc. 25, 452-453, 1992.

Duan, H., Gao, F., Li, S., Nagata, T.: Postnatal development of esophageal epithelium in mouse: a light and electron microscopic radioautographic study. Cell. Mol. Biol. 39, 309-316, 1993.

Duan, H., Gao, F., Oguchi, K., Nagata, T.: Light and electron microscopic radioautographic study on the incorporation of ${ }^{3} \mathrm{H}$-thymidine into the lung by means of a new nebulizer. Drug Res. 44, 880-883, 1994. 
Feulgen, R., Rossenbeck, H.: Mikroskopische-chemischer Nachweis einer Nukeinsaeure von Thymus der Thymonukeinsaeure Z. Physik. Chem. 135, 203-248, 1924.

Fujii, Y., Ohno, S., Yamabayashi, S., Usuda, N., Saito, H., Furuta, S., Nagata, T.: Electron microscopic radioautography of DNA synthesis in primary cultured cells from an IgG myeloma patient. J. Clin. Electr. Microsc. 13, 582-583, 1980.

Gao, F.: Study on the macromolecular synthesis in aging mouse seminiferous tubules by light and electron microscopic radioautography. Cell. Mol. Biol. 39, 659-672, 1993.

Gao, F., Toriyama, K., Nagata, T.: Light microscopic radioautographic study on the DNA synthesis of prenatal and postnatal aging mouse retina after labeled thymidine injection. Cell. Mol. Biol. 38, 661-668, 1992a.

Gao, F., Li, S., Duan, H., Ma, H., Nagata, T.: Electron microscopic radioautography on the DNA synthesis of prenatal and postnatal mice retina after labeled thymidine injection. J. Clin. Electron Microsc. 25, 721-722, $1992 \mathrm{~b}$.

Gao, F., Toriyama, K., Ma, H., Nagata, T.: Light microscopic radioautographic study on DNA synthesis in aging mice corneas. Cell. Mol. Biol. 39, 435-441, 1993.

Gao, F., Ma, H., Sun, L., Jin, C., Nagata, T.: Electron microscopic radioautographic study on the nucleic acids and protein synthesis in the aging mouse testis. Med. Electron Microsc. 27, 360-362, 1994.

Gao, F., Chen, S., Sun, L., Kang, W., Wang, Z., Nagata, T.: Radioautographic study of the macromolecular synthesis of Leydig cells in aging mice testis. Cell. Mol. Biol. 41, 145-150, 1995a.

Gao, F., Jin, C., Ma, H., Sun, L., Nagata, T.: Ultrastructural and radioautographic studies on DNA synthesis in Leydig cells of aging mouse testis. Cell. Mol. Biol. 41, 151-160, 1995b.

Gunarso, W.: Radioautographic studies on the nucleic acid synthesis of the retina of chick embryo. I. Light microscopic radioautography. Shinshu Med. J. 32, 231-240, 1984a.

Gunarso, W.: Radioautographic studies on the nucleic acid synthesis of the retina of chick embryo. II. Electron microscopic radioautography. Shinshu Med. J. 32, 241-248, 1984b.

Gunarso, W., Gao, F., Cui, H., Ma, H., Nagata, T.: A light and electron microscopic radioautographic study on RNA synthesis in the retina of chick embryo. Acta Histochem. 98, 309-32, 1996.

Gunarso, W., Gao, F., Nagata, T.: Development and DNA synthesis in the retina of chick embryo observed by light and electron microscopic radioautography. Cell. Mol. Biol. 43, 189-201, 1997.

Hanai, T.: Light microscopic radioautographic study of DNA synthesis in the kidneys of aging mice. Cell. Mol. Biol. 39, 81-91, 1993.

Hanai, T., Nagata, T.: Electron microscopic radioautographic study on DNA and RNA synthesis in perinatal mouse kidney. In, Radioautography in Medicine, Nagata, T., Ed., pp. 127-131, Shinshu University Press, Matsumoto, 1994a.

Hanai, T., Nagata, T.: Study on the nucleic acid synthesis in the aging mouse kidney by light and electron microscopic radioautography. In, Radioautography in Medicine, Nagata, T., Ed., pp. 209-214, Shinshu University Press, Matsumoto, 1994b.

Hanai, T., Nagata, T.: Electron microscopic study on nucleic acid synthesis in perinatal mouse kidney tissue. Med. Electron Microsc. 27, 355-357, 1994c.

Hanai, T., Usuda, N., Morita, T., Shimizu, T., Nagata, T.: Proliferative activity in the kidneys of aging mice evaluated by PCNA/cyclin immunohistochemistry. Cell. Mol. Biol. 39, 181-191, 1993. 
Hayashi, K., Gao, F., Nagata, T.: Radioautographic study on ${ }^{3} \mathrm{H}$-thymidine incorporation at different stages of muscle development in aging mice. Cell. Mol. Biol. 39, 553-560, 1993.

Ito, M.: The radioautographic studies on aging change of DNA synthesis and the ultrastructural development of mouse adrenal gland. Cell. Mol. Biol. 42, 279-292, 1996.

Ito, M., Nagata, T.: Electron microscopic radioautographic studies on DNA synthesis and ultrastructure of aging mouse adrenal gland. Med. Electron Microsc. 29, 145-152, 1996.

Izumiyama, K., Kogure, K., Kataoka, S., Nagata, T.: Quantitative analysis of glucose after transient ischemia in the gerbil hippocampus by light and electron microscope radioautography. Brain Res. 416, 175-179, 1987.

Jamieson, J. D., Palade, G. E.: Intracellular transport of secretory proteins in the pancreatic exocrine cells. J. Cell Biol. 34, 577-615, 1967.

Jin, C.: Study on DNA synthesis of aging mouse colon by light and electron microscopic radioautography. Cell. Mol. Biol. 42, 255-268, 1996.

Jin, C., Nagata, T.: Light microscopic radioautographic study on DNA synthesis in cecal epithelial cells of aging mice. J. Histochem. Cytochem. 43, 1223-1228, 1995a.

Jin, C., Nagata, T.: Electron microscopic radioautographic study on DNA synthesis in cecal epithelial cells of aging mice. Med. Electron Microsc. 28, 71-75, 1995b.

Joukura, K.: The aging changes of glycoconjugate synthesis in mouse kidney studied by ${ }^{3} \mathrm{H}-$ glucosamine radioautography. Acta Histochem. Cytochem. 29, 57-63, 1996.

Joukura, K., Nagata, T.: Aging changes of ${ }^{3} \mathrm{H}$-glucosamine incorporation into mouse kidney observed by radioautography. Acta Histochem. Cytochem. 28, 494-494, 1995.

Joukura, K., Usuda, N., Nagata, T.: Quantitative study on the aging change of glycoconjugates synthesis in aging mouse kidney. Proc. Xth Internat. Cong. Histochem. Cytochem., Acta Histochem. Cytochem. 29, Suppl. 507-508, 1996.

Kobayashi, K., Nagata, T.: Light microscopic radioautographic studies on DNA, RNA and protein syntheses in human synovial membranes of rheumatoid arthritis patients. J. Histochem. Cytochem. 42, 982-982, 1994.

Komiyama, K., Iida, F., Furihara, R., Murata, F., Nagata, T.: Electron microscopic radioautographic study on $125 \mathrm{I}$-albumin in rat gastric mucosal epithelia. J. Clin. Electron Microsc. 11, 428-429, 1978.

Kong, Y.: Electron microscopic radioautographic study on DNA synthesis in perinatal mouse retina. Cell. Mol. Biol. 39, 55-64, 1993.

Kong, Y., Nagata, T.: Electron microscopic radioautographic study on nucleic acid synthesis of perinatal mouse retina. Med. Electron Microsc. 27, 366-368, 1994.

Kong, Y., Usuda, N., Nagata, T.: Radioautographic study on DNA synthesis of the retina and retinal pigment epithelium of developing mouse embryo. Cell. Mol. Biol. 38, 263-272, 1992a.

Kong, Y., Usuda, N., Morita, T., Hanai, T., Nagata, T.: Study on RNA synthesis in the retina and retinal pigment epithelium of mice by light microscopic radioautography. Cell. Mol. Biol. 38, 669-678, 1992b.

Leblond, C. P.: Localization of newly administered iodine in the thyroid gland as indicated by radioiodine. J. Anat. 77, 149-152, 1943.

Leblond, C. P.: The life history of cells in renewing systems. Am. J. Anat. 160, 113-158, 1981. 
Leblond, C. P., Messier, B.: Renewal of chief cells and goblet cells in the small intestine as shown by radioautography after injection of thymidine-3 $\mathrm{H}$ into mice. Anat. Rec. 132: 247-259. 1958.

Li, S.: Relationship between cellular DNA synthesis, PCNA expression and sex steroid hormone receptor status in the developing mouse ovary, uterus and oviduct. Histochemistry 102, 405-413, 1994.

Li, S., Nagata, T.: Nucleic acid synthesis in the developing mouse ovary, uterus and oviduct studied by light and electron microscopic radioautography. Cell. Mol. Biol. 41, 185195, 1995.

Li, S., Gao, F., Duan, H., Nagata, T.: Radioautographic study on the uptake of ${ }^{35} \mathrm{SO}_{4}$ in mouse ovary during the estrus cycle. J. Clin. Electron Microsc. 25, 709-710, 1992.

Liang, Y.: Light microscopic radioautographic study on RNA synthesis in the adrenal glands of aging mice. Acta Histochem. Cytochem. 31, 203-210, 1998.

Liang, Y., Ito, M., Nagata, T.: Light and electron microscopic radioautographic studies on RNA synthesis in aging mouse adrenal gland. Acta Anat. Nippon. 74, 291-300, 1999.

Ma, H.: Light microscopic radioautographic study on DNA synthesis of the livers in aging mice. Acta Anat. Nippon. 63, 137-147, 1988.

Ma, H., Nagata, T.: Electron microscopic radioautographic study on DNA synthesis of the livers in aging mice. J. Clin. Electron Microsc. 21, 335-343, 1988a.

Ma, H., Nagata, T.: Studies on DNA synthesis of aging mice by means of electron microscopic radioautography. J. Clin. Electron Microsc. 21, 715-716, 1988 b.

Ma, H., Nagata, T.: Electron microscopic radioautographic studies on DNA synthesis in the hepatocytes of aging mice as observed by image analysis. Cell. Mol. Biol. 36, 73-84, 1990a.

Ma, H., Nagata, T.: Study on RNA synthesis in the livers of aging mice by means of electron microscopic radioautography. Cell. Mol. Biol. 36, 589-600, $1990 \mathrm{~b}$.

Ma, H., Nagata, T.: Collagen and protein synthesis in the livers of aging mice as studied by electron microsopic radioautography. Ann. Microsc. 1, 13-22, 2000.

Ma, H., Gao, F., Olea, M. T., Nagata, T.: Protein synthesis in the livers of aging mice studied by electron microscopic radioautography. Cell. Mol. Biol. 37, 607-615, 1991.

Matsumura, H., Kobayashi, Y., Kobayashi, K., Nagata, T.: Light microscopic radioautographic study of DNA synthesis in the lung of aging salamander, Hynobius nebulosus. J. Histochem. Cytochem. 42, 1004-1004, 1994.

Momose, Y., Nagata, T.: Radioautographic study on the intracellular localization of a hypolipidemic agent, bezafibrate, a peroxisome proliferator, in cultured rat hepatocytes. Cell. Mol. Biol. 39, 773-781, 1993a.

Momose, Y., Naito, J., Nagata, T.: Radioautographic study on the localization of an antiallergic agent, tranilast, in the rat liver. Cell. Mol. Biol. 35, 347-355, 1989.

Momose, Y., Shibata, N., Kiyosawa, I., Naito, J., Watanabe, T., Horie, S., Yamada, J., Suga, T., Nagata, T.: Morphometric evaluation of species differences in the effects of bezafibrate, a hypolipidemic agent, on hepatic peroxisomes and mitochondria. J. Toxicol. Pathol. 6, 33-45, 1993b.

Momose, Y., Naito, J., Suzawa, H., Kanzawa, M., Nagata, T.: Radioautographic study on the intracellular localization of bezafibrate in cultured rat hepatoctyes. Acta Histochem. Cytochem. 28, 61-66, 1995.

Morita, T.: Radioautographic study on the aging change of ${ }^{3} \mathrm{H}$-glucosamine uptake in mouse ileum. Cell. Mol. Biol. 39, 875-884, 1993. 
Morita, T., Usuda, N. Hanai, T., Nagata, T.: Changes of colon epithelium proliferation due to individual aging with PCNA/cyclin immunostaining comparing with $3 \mathrm{H}-$ thymidine radioautography. Histochemistry 101, 13-20, 1994.

Murata, F., Momose,Y. , Yoshida, K., Nagata, T.: Incorporation of ${ }^{3} \mathrm{H}$-thymidine into the nucleus of mast cells in adult rat peritoneum. Shinshu Med. J. 25, 72-77, 1977a.

Murata, F., Momose, Y., Yoshida, K., Ohno, S., Nagata, T.: Nucleic acid and mucosubstance metabolism of mastocytoma cells by means of electron microscopic radioautography. Acta Pharmacol. Toxicol. 41, 58-59, 1977b.

Murata, F., Yoshida, K., Ohno, S., Nagata, T.: Ultrastructural and electron microscopic radioautographic studies on the mastocytoma cells and mast cells. J. Clin. Electron Microsc. 11, 561-562, 1978.

Murata, F., Yoshida, K., Ohno, S., Nagata, T.: Mucosubstances of rabbit granulocytes studied by means of electron microscopic radioautography and X-ray microanalysis. Histochemistry 61, 139-150, 1979.

Nagata, T.: On the relationship between cell division and cytochrome oxidase in the Yoshida sarcoma cells. Shinshu Med. J. 5: 383-386, 1956.

Nagata, T.: Studies on the amitosis in the Yoshida sarcoma cells. I. Observation on the smear preparation under normal conditions. Med. J. Shinshu Univ. 2: 187-198, 1957a.

Nagata, T.: Studies on the amitosis in the Yoshida sarcoma cells. II. Phase-contrast microscopic observations under normal conditions. Med. J. Shinshu Univ. 2: 199$207,1957 b$.

Nagata, T.: Cell divisions in the liver of the fetal and newborn dogs. Med. J. Shinshu Univ. 4: 65-73, 1959.

Nagata, T.: A radioautographic study of the DNA synthesis in rat liver, with special reference to binucleate cells. Med. J. Shinshu Univ. 7, 17-25, 1962.

Nagata, T.: A quantitative study on the ganglion cells in the small intestine of the dog. Med. J. Shinshu Univ. 10, 1-11, 1965.

Nagata, T.: A radioautographic study on the RNA synthesis in the hepatic and the intestinal epithelial cells of mice after feeding with special reference to binuclearity. Med. J. Shinshu Univ. 11, 49-61, 1966.

Nagata, T.: On the increase of binucleate cells in the ganglion cells of dog small intestine due to experimental ischemia. Med. J. Shinshu Univ. 12, 93-113, 1967a.

Nagata, T.: A radioautographic study on the protein synthesis in the hepatic and the intestinal epithelial cells of mice, with special reference to binucleate cells. Med. J. Shinshu Univ. 12, 247-257, 1967b.

Nagata, T.: Chapter 3. Application of microspectrophotometry to various substances. In , Introduction to Microspectrophotometry. Isaka, S., Nagata, T., Inui, N., Eds., Olympus Co., Tokyo, pp. 49-155, 1972a.

Nagata, T.: Electron microscopic dry-mounting autoradiography. Proc. 4th Internat. Cong. Histochem. Cytochem. Kyoto, pp. 43-44, 1972b.

Nagata, T.: Electron microscopic radioautography of intramitochondrial RNA synthesis of HeLa cells in culture. Histochemie 32, 163-170, 1972c.

Nagata, T.: Quantitative electron microscope radioautography of intramitochondrial nucleic acid synthesis. Acta Histochem. Cytochem. 5, 201-203, 1972d.

Nagata, T.: Electron microscopic observation of target cells previously observed by phasecontrast microscopy: Electron microscopic radioautography of laser beam irradiated cultured cells. J. Clin. Electron Microsc. 17, 589-590, 1984. 
Nagata, T.: Principles and techniques of radioautography. In, Histo- and Cyto-chemistry 1985, Japan Society of Histochemistry and Cytochemistry, Ed., Gakusai Kikaku Co., Tokyo, pp. 207-226, 1985.

Nagata, T.: Electron microscopic radioautography and analytical electron microscopy. J. Clin. Electron Microsc. 24, 441-442, 1991.

Nagata, T.: Radiolabeling of soluble and insoluble compounds as demonstrated by light and electron microscopy. Recent Advances in Cellular and Molecular Biology, Wegmann, R. J., Wegmann, M. A., Eds. Peters Press, Leuven, Vol. 6, pp. 9-21, 1992.

Nagata, T.: Quantitative analysis of histochemical reactions: Image analysis of light and electron microscopic radioautograms. Acta Histochem. Cytochem. 26, 281-291, 1993a.

Nagata, T. Quantitative light and electron microscopic radioautographic studies on macromolecular synthesis in several organs of prenatal and postnatal aging mice. Chinese J. Histochem. Cytochem. 2: 106-108, $1993 \mathrm{~b}$.

Nagata, T.: Electron microscopic radioautography with cryo-fixation and dry-mounting procedure. Acta Histochem. Cytochem. 27: 471-489, 1994a.

Nagata, T.: Application of electron microscopic radioautography to clinical electron microscopy. Med. Electron Microsc. 27; 191-212, 1994b.

Nagata, T.: Radioautography in Medicine. Shinshu University Press, 268pp, Matsumoto, 1994c.

Nagata, T.: Radioautography, general and special. In, Histo- and Cyto-chemistry 1994, Japan Society of Histochemistry and Cytochemistry, ed, pp. 219-231, Gakusai Kikaku Co., Tokyo, $1994 \mathrm{~d}$.

Nagata, T., Application of electron microscopic radioautography to clinical electron microscopy. Med. Electron Microsc. 27, 191-212, 1994e.

Nagata, T.: Light and electron microscopic radioautographic study on macromolecular synthesis in digestive organs of aging mice. Cell. Mol. Biol. 41, 21-38, 1995a.

Nagata, T.: Histochemistry of the organs: Application of histochemistry to anatomy. Acta Anat. Nippon. 70, 448-471, 1995b.

Nagata, T.: Three-dimensional observation of whole mount cultured cells stained with histochemical reactions by ultrahigh voltage electron microscopy. Cell. Mol. Biol. 41, 783-792, 1995c.

Nagata, T.: Morphometry in anatomy: image analysis on fine structure and histochemical reactions with special reference to radioautography. Ital. J. Anat. 100 (Suppl. 1), 591-605, 1995d.

Nagata, T.: Technique and application of electron microscopic radioautography. J. Electron Microsc. 45, 258-274, 1996a.

Nagata, T.: Techniques of light and electron microscopic radioautography. In, Histochemistry and Cytochemistry 1996. Proc. Xth Internat. Congr. Histochem. Cytochem. Acta Histochem. Cytochem. 29 (Suppl.), 343-344, 1996b.

Nagata, T.: Remarks: Radioautographology, general and special. Cell. Mol. Biol. 42 (Suppl.), 11-12, 1996c.

Nagata, T.: On the terminology of radioautography vs. autoradiography. J. Histochem. Cytochem. 44, 1209-1209, 1996d.

Nagata, T.: Techniques and applications of microscopic radioautography. Histol. Histopathol. 12, 1091-1124, 1997a.

Nagata T.: Three-dimensional observation on whole mount cultured cells and thick sections stained with histochemical reactions by high voltage electron microscopy. In, 
Recent Advances in Microscopy of Cells, Tissues and Organs, Motta, P., Ed., Antonio Delfino Editore, Roma, pp. 37-44, 1997b.

Nagata, T.: Radioautographic study on collagen synthesis in the ocular tissues. J. Kaken Eye Res. 15, 1-9, 1997c.

Nagata, T.: Techniques of radioautography for medical and biological research. Braz. J. Biol. Med. Res. 31, 185-195, 1998a.

Nagata, T.: Radioautographology, the advocacy of a new concept. Braz. J. Biol. Med. Res. 31, 201-241, 1998b.

Nagata, T.: Radioautographic studies on DNA synthesis of the bone and skin of aging salamander. Bull. Nagano Women's Jr. College 6, 1-14, 1998c.

Nagata, T.: 3D observation of cell organelles by high voltage electron microscopy. Microscopy and Analysis, Asia Pacific Edition, 9, 29-32, 1999a.

Nagata, T.: Application of histochemistry to anatomy: Histochemistry of the organs, a novel concept. Proc. XV Congress of the International Federation of Associations of Anatomists, Ital. J. Anat. Embryol. 104 (Suppl. 1), 486-486, 1999b.

Nagata, T.: Aging changes of macromolecular synthesis in various organ systems as observed by microscopic radioautography after incorporation of radiolabeled precursors. Methods Find. Exp. Clin. Pharmacol. 21, 683-706, 1999c.

Nagata, T.: Radioautographic study on protein synthesis in mouse cornea. J. Kaken Eye Res. 8, 8-14, 1999d.

Nagata, T.: Radioautographology, general and special: a novel concept. Ital. J. Anat. Embryol. 104 (Suppl. 1), 487-487, 1999e.

Nagata, T.: Three-dimensional observations on thick biological specimens by high voltage electron microscopy. Image Analysis Stereolog. 19, 51-56, 2000a.

Nagata, T.: Biological microanalysis of radiolabeled and unlabeled compounds by radioautography and X-ray microanalysis. Scanning Microscopy International, 14, on line, 2000b.

Nagata, T.: Electron microscopic radioautographic study on protein synthesis in pancreatic cells of perinatal and aging mice. Bull. Nagano Women's Jr. College 8, 1-22, 2000c.

Nagata, T.: Light microscopic radioautographic study on radiosulfate incorporation into the tracheal cartilage in aging mice. Acta Histochem. Cytochem. 32, 377-383, 2000d.

Nagata, T.: Introductory remarks: Special radioautographology. Cell. Mol. Biol. 46 (Congress Suppl.), 161-161, 2000e.

Nagata, T.: Special radioautographology: the eye. J. Kaken Eye Res. 18, 1-13, 2000f.

Nagata, T.: Three-dimensional high voltage electron microscopy of thick biological specimens. Micron 32, 387-404, 2001a.

Nagata, T.: Three-dimensional and four-dimensional observation of histochemical and cytochemical specimens by high voltage electron microscopy. Acta Histochem. Cytochem. 34, 153-169, 2001 b.

Nagata, T. : Special cytochemistry in cell biology. In, Internat. Rev. Cytol. Jeon, K.W., ed., Vol. 211, Chapter 2, Academic Press, New York, pp. 33-154, 2001c.

Nagata, T. : Radioautographology General and Special, In, Prog. Histochem. Cytochem., Graumann, W., Ed., Vol. 37 No. 2, Urban \& Fischer, Jena, pp. 57-226, 2002.

Nagata T.: Light and electron microscopic study on macromolecular synthesis in amitotic hepatocyte mitochondria of aging mice. Cell. Mol. Biol. 49, 591-611, 2003.

Nagata, T.: X-ray microanalysis of biological specimens by high voltage electron microscopy. In, Prog. Histochem. Cytochem., Graumann, W., Ed., Vol. 39, No. 4, Urban \& Fischer Verlag, Jena, pp. 185-320, 2004. 
Nagata T.: Aging changes of macromolecular synthesis in the uro-genital organs as revealed by electron microscopic radioautography. Ann. Rev. Biomed. Sci. 6, 13-78, 2005.

Nagata T.: Electron microscopic radioautographic study on protein synthesis in hepatocyte mitochondria of developing mice. Ann. Microsc. 6, 43-54, $2006 \mathrm{a}$.

Nagata T.: Electron microscopic radioautographic study on nucleic acids synthesis in hepatocyte mitochondria of developing mice. The Sci. World J. 6: 1583-1598, 2006b.

Nagata T.: Macromolecular synthesis in hepatocyte mitochondria of aging mice as revealed by electron microscopic radioautography. I: Nucleic acid synthesis. In, Modern Research and Educational Topics in Microscopy. Mendez-Vilas, A. and Diaz, J. Eds., Formatex Micrscopy Series No. 3, Vol. 1, Formatex, Badajoz, Spain, pp. 245258, 2007a.

Nagata T.: Macromolecular synthesis in hepatocyte mitochondria of aging mice as revealed by electron microscopic radioautography. II: Protein synthesis. In, Modern Research and Educational Topics in Microscopy. Mendez-Vilas, A. and Diaz, J. eds., Formatex Micrscopy Series No. 3, Vol. 1, Formatex, Badajoz, Spain, pp. 259-271, 2007b.

Nagata, T.: Electron microscopic radioautographic study on macromolecular synthesis in hepatocyte mitochondria of aging mouse. J. Cell Tissue Res. 7, 1019-1029, 2007c.

Nagata, T.; Electron microscopic radioautographic study on nucleic acids synthesis in hepatocyte mitochondria of developing mice. Trends Cell Molec. Biol. 2, 19-33, 2007d.

Nagata, T.; Aging changes of macromolecular synthesis in the mitochondria of mouse hepatocytes as revealed by microscopic radioautography. Ann. Rev. Biomed. Sci. 9, 30-36, 2007e.

Nagata, T.: Radioautographology, Bull. Shinshu Institute Alternat. Med. 2, 3-32, $2007 f$.

Nagata, T.: Electron microscopic radioautographic study on mitochondrial DNA synthesis in adrenal cortical cells of developing mice. J. Cell. Tis. Res. 8, 1303-1312, 2008a.

Nagata T.: Electron microscopic radioautographic study on mitochondrial DNA synthesis in adrenal cortical cells of developing and aging mice. The Sci. World J. 8, 683-697. 2008b.

Nagata, T.: Sexual difference between the macromolecular synthesis of hepatocyte mitochondria in male and female mice in aging as revealed by electron microscopic radioautography. Chapter 22. In, Women and Aging: New Research, H. T. Bennninghouse, A. D. Rosset, Eds. Nova Biomed. Books, New York, pp. 461-487, 2009a

Nagata, T.: Protein synthesis in hepatocytes of mice as revealed by electron microscopic radioautography. In, Protein Biosynthesis. Esterhouse, T. E. and Petrinos, L. B., Eds., Nova Biomed. Books, New York, pp. 133-161, 2009 b.

Nagata, T.: Electron microscopic radioatuographic studies on macromolecular synthesis in mitochondria of various cells. 18EMSM Conference Proc. 9th Asia-Pacific Microscopy Conference (APMC9), Kuala Lumpur, Malaysia, pp. 48-50, 2009c.

Nagata, T.: Recent studies on macromolecular synthesis labeled with ${ }^{3} \mathrm{H}$-thymidine in various organs as revealed by electron microscopic radioautography. Current Radiopharmaceutics 2, 118-128, 2009d.

Nagata, T.: Electron microscopic radioautographic study on mitochondrial DNA synthesis in adrenal medullary cells of developing and aging mice. J. Cell Tissue Res. 9, 17931802,2009 e. 
Nagata, T.: Applications of high voltage electron microscopy to thick biological specimens. Ann. Microsc. 9, 4-40, $2009 f$.

Nagata, T.: Electron microscopic radioautographic study on DNA synthesis of mitochondria in adrenal medullary cells of aging mice. Open Anat. J. 1, 14-24, 2009g.

Nagata, T.: Electron microscopic radioautographic studies on macromolecular synthesis in mitochondria of animal cells in aging. Ann. Rev. Biomed. Sci. 11, 1-17, 2009h.

Nagata, T.: Electron microscopic radioautographic studies on macromoleclular synthesis in mitochondria of some organs in aging animals. Bull. Shinshu Inst. Alternat. Med. Welfare 4, 15-38, 2009i.

Nagata, T.: Electron microscopic radioautographic study on mitochondrial DNA synthesis in adreno-cortical cells of aging ddY mice. Bull. Shinshu Inst. Alternat. Med. Welfare 4, 51-66, 2009j.

Nagata T.: Electron microscopic radioautographic study on mitochondrial RNA synthesis in adrenocortical cells of aging mice. Open Anat J. 2, 91-97, 2010a.

Nagata T. Electron microscopic radioautographic study on mitochondrial RNA synthesis in adrenal medullary cells of aging and senescent mice. J Cell Tissue Res. 10, 2213$2222,2010 b$.

Nagata, T.: Macromolecular synthesis in the livers of aging mice as revealed by electron microscopic radioautography. In, Prog. Histochem. Cytochem., Sasse, D., Ed., Elsevier, Amsterdam, Boston, London, New York, Oxford, Paris, Philadelphia, San Diego, St. Louis, Vol. 45, No. 1, pp. 1-80, 2010c.

Nagata, T.: Electron microscopic radioautographic study on protein synthesis of mitochondria in adrenal medullary cells of aging mice. Bulletin Shinshu Inst Alternat Med Welfare 5, 25-37, 2010d.

Nagata, T.: Electron microscopic radioautographic study on mitochondrial RNA synthesis in adrenal cortical and medullary cells of aging mice. J. Biomed. Sci. Enginer. 4, 219232, 2010e.

Nagata, T.: Electron microscopic radioautographic study on protein synthesis of mitochondria in adrenal cortical cells of aging mice. Bulletin Shinshu Inst. Alternat. Med. Welfare 5, 38-52, 2010 f.

Nagata T.: Electron microscopic radioautographic study on mitochondrial DNA, RNA and protein synthesis in adrenal cells of aging mice. Formatex Microscopy Series No. 3, Vol. 3, Formatex, Badajoz, Spain, in press, 2010g.

Nagata, T.: Electron microscopic radioautographic studies on macromolecular synthesis in mitochondria of animal cells in aging. Ann. Rev. Biomed. Sci. 12, 1-29, 2010h.

Nagata, T., Cui, H., Gao, F.: Radioautographic study on glycoprotein synthesis in the ocular tissues. J. Kaken Eye Res. 13, 11-18, 1995.

Nagata, T., Cui, H., Kong, Y.: The localization of TGF-b1 and its mRNA in the spinal cords of prenatal and postnatal aging mice demonstrated with immunohistochemical and in situ hybridization techniques. Bull. Nagano Women's Jr. College, 7, 75-88, 1999a.

Nagata, T., Cui, H., Liang, Y.: Light microscopic radioautographic study on the protein synthesis in the cerebellum of aging mouse. Bull. Nagano Women's Jr. College, 9, 41-60 (2001).

Nagata, T., Fujii, Y., Usuda, N.: Demonstration of extranuclear nucleic acid synthesis in mammalian cells under experimental conditions by electron microscopic radioautography. Proc. 10th Internat. Congr. Electr. Microsc. 2, 305-306, 1982b.

Nagata, T., Hirano, I., Shibata, O., Nagata, T.: A radioautographic study on the DNA synthesis in the hepatic and the pancreatic acinar cells of mice during the postnatal 
growth, with special reference to binuclearity. Med. J. Shinshu Univ. 11, 35-42, 1966.

Nagata, T., Ito, M., Chen, S.: Aging changes of DNA synthesis in the submandibular glands of mice as observed by light and electron microscopic radioautography. Ann. Microsc. 1, 4-12, 2000a.

Nagata, T. Ito, M., Liang, Y.: Study of the effects of aging on macromolecular synthesis in mouse steroid secreting cells using microscopic radioautography. Methods Find. Exp. Clin. Pharmacol. 22, 5-18, 2000b.

Nagata, T., Iwadare, I., Murata, F.: Electron microscopic radioautography of nucleic acid synthesis in cultured cells treated with several carcinogens. Acta Pharmacol. Toxicol. 41, 64-65, 1977c.

Nagata, T., Kawahara, I.: Radioautographic study of the synthesis of sulfomucin in digestive organs of mice. J. Trace Microprobe Analysis 17, 339-355, 1999.

Nagata, T., Kawahara, I., Usuda, N., Maruyama, M., Ma, H.: Radioautographic studies on the glycoconjugate synthesis in the gastrointestinal mucosa of the mouse. In, Glycoconjugate in Medicine, Ohyama, M., Muramatsu, T., Eds, pp. 251-256, Professional Postgrad. Service, Tokyo, 1988a.

Nagata, T., Kong, Y.: Distribution and localization of TGFb1 and bFGF, and their mRNAs in aging mice. Bull. Nagano Women's Jr. College 6, 87-105, 1998.

Nagata, T., Ma, H., Electron microscopic radioautographic study on mitochondrial DNA synthesis in hepatocytes of aging mouse. Ann. Microsc. 5, 4-18, $2005 \mathrm{a}$.

Nagata, T., Ma, H., Electron microscopic radioautographic study on RNA synthesis in hepatocyte mitochondria of aging mouse. Microsc. Res. Tech. 67, 55-64, 2005b.

Nagata, T., Momoze, S.: Aging changes of the amitotic and binucleate cells in dog livers. Acta Anat. Nipponica 34, 187-190, 1959.

Nagata, T., Morita, T., I. Kawahara, I.: Radioautographic studies on radiosulfate incorporation in the digestive organs of mice. Histol. Histopathol. 14, 1-8, 1999b.

Nagata, T., Murata, F.: Electron microscopic dry-mounting radioautography for diffusible compounds by means of ultracryotomy. Histochemistry 54, 75-82, 1977.

Nagata, T., Murata, F., Yoshida, K., Ohno, S., Iwadare, N.: Whole mount radioautography of cultured cells as observed by high voltage electron microscopy. Proc. Fifth Internat. Conf. High Voltage Electron Microsc. 347-350, 1977d.

Nagata, T., Nawa, T.: A modification of dry-mounting technique for radioautography of water-soluble compounds. Histochemie 7, 370-371, 1966a.

Nagata, T., Nawa, T.: A radioautographic study on the nucleic acids synthesis of binucleate cells in cultivated fibroblasts of chick embryos. Med. J. Shinshu Univ. 11, 1-5, 1966b.

Nagata, T., Nawa, T., Yokota, S.: A new technique for electron microscopic dry-mounting radioautography of soluble compounds. Histochemie 18, 241-249, 1969.

Nagata, T., Nishigaki, T., Momose, Y.: Localization of anti-allergic agent in rat mast cells demonstrated by light and electron microscopic radioautography. Acta Histochem. Cytochem. 19, 669-683, 1986b.

Nagata, T., Ohno, S., Kawahara, I., Yamabayashi, S., Fujii, Y., Murata, F.: Light and electron microscopic radioautography of nucleic acid synthesis in mitochondria and peroxisomes of rat hepatic cells during and after DEHP administration. Acta Histochem. Cytochem. 16, 610-611, 1979.

Nagata, T., Ohno, S., Murata, F.: Electron microscopic dry-mounting radioautography for soluble compounds. Acta Phamacol. Toxicol. 41, 62-63, 1977a. 
Nagata, T., Ohno, S., Yoshida, K., Murata, F.: Nucleic acid synthesis in proliferating peroxisomes of rat liver as revealed by electron microscopical radioautography. Histochem. J. 14, 197-204, 1982a.

Nagata, T., Olea, M. T.: Electron microscopic radioautographic study on the protein synthesis in aging mouse spleen. Bull. Nagano Women's Jr. College 7, 1-9, 1999.

Nagata, T., Shibata, O., Omochi, S.: A new method for radioautographic osbservation on isolated cells. Histochemie 2, 255-259, 1961

Nagata, T., Shibata, O., Nawa, T.: Simplified methods for mass production of radioautograms. -Acta Anat. Nippon.42, 162-166, 1967a.

Nagata, T., Shibata, O., Nawa, T.: Incorporation of tritiated thymidine into mitochondrial DNA of the liver and kidney cells of chickens and mice in tissue culture. Histochemie 10, 305-308, 1967b.

Nagata, T., Shimamura, K., Onozawa, M., Kondo, T., Ohkubo, K., Momoze, S.: Relationship of binuclearity to cell function in some organs. I. Frequencies of binucleate cells in some organs of toads in summer and winter. Med. J. Shinshu Univ. 5, 147-152, 1960a.

Nagata, T., Shimamura, K., Kondo, T., Onozawa, M., Momoze, S., Okubo, M.: Relationship of binuclearity to cell function in some organs. II. Variation of frequencies of binucleate cells in some organs of dogs owing to aging. Med. J. Shinshu Univ. 5, 153-158, 1960b.

Nagata, T., Steggerda, F. R.: Histological study on the deganglionated small intestine of the dog. Physiologist 6, 242-242, 1963.

Nagata, T., Steggerda, F. R.: Observations on the increase of binucleate cells in the ganglion cells of the dog's intestine due to experimental ischemia. Anat. Rec. 148, 315-315, 1964.

Nagata, T., Toriyama, K., Kong, Y., Jin, C., Gao, F.: Radioautographic study on DNA synthesis in the ciliary bodies of aging mice. J. Kaken Eye Res.12, 1-11, 1994.

Nagata, T., Usuda, N.: Image processing of electron microscopic radioautograms in clinical electron microscopy. J. Clin. Electron. Microsc. 18, 451-452, 1985.

Nagata, T., Usuda, N.: Studies on the nucleic acid synthesis in pancreatic acinar cells of aging mice by means of electron microscopic radioautography. J. Clin. Electron Microsc. 19, 486-487, 1986.

Nagata, T., Usuda, N.: Electron microscopic radioautography of protein synthesis in pancreatic acinar cells of aging mice. Acta Histochem. Cytochem. 26, 481-481, 1993a.

Nagata, T., Usuda, N.: In situ hybridization by electron microscopy using radioactive probes. J. Histochem. Cytochem. 41, 1119-1119, $1993 \mathrm{~b}$.

Nagata, T., Usuda, N., Ma, H.: Electron microscopic radioautography of nucleic acid synthesis in pancreatic acinar cells of prenatal and postnatal aging mice. Proc. XIth Intern. Cong. Electr. Microsc. 3, 2281-2282, 1984.

Nagata, T., Usuda, N., Ma, H.: Electron microscopic radioautography of lipid synthesis in pancreatic cells of aging mice. J. Clin. Electr. Microsc. 23, 841-842, 1990.

Nagata, T., Usuda, N., Maruyama, M., Ma, H.: Electron microscopic radioautographic study on lipid synthesis in perinatal mouse pancreas. J. Clin. Electr. Microsc. 21, 756-757, 1988b.

Nagata, T., Usuda, N., Suzawa, H., Kanzawa, M.: Incorporation of ${ }^{3} \mathrm{H}$-glucosamine into the pancreatic cells of aging mice as demonstrated by electron microscopic radioautography. J. Clin. Electron Microsc. 25, 646-647, 1992. 
Nagata, T., Yamabayashi, S.: Intracellular localization of $3 \mathrm{H}-$-befunolol by means of electron microscopic radioautography of cryo-fixed ultrathin sections. J. Clin. Electron Microsc. 16, 737-738, 1983.

Nagata, T., Yoshida, K., Murata, F.: Demonstration of hot and cold mercury in the human thyroid tissues by means of radioautography and chemography. Acta Pharmacol. Toxicol. 41, 60-61, 1977b.

Nagata, T., Yoshida, K., Ohno, S., Murata, F.: Ultrastructural localization of soluble and insoluble ${ }^{3} \mathrm{H}$-methyl prednisolone as revealed by electron microscopic drymounting radioautography. Proc. 9th Internat. Congr. Electr. Microsc. 2, 40-41, 1978 b.

Nishigaki, T., Momose, Y., Nagata, T.: Light microscopic radioautographic study of the localization of anti-allergic agent, tranilast, in rat mast cells. Histochem. J. 19, 533536, 1987.

Nishigaki, T., Momose, Y., Nagata, T.: Electron microscopic radioautographic study of the localization of an anti-allergic agent, tranilast, in rat mast cells. Cell. Mol. Biol. 36, 65-71, 1990a.

Nishigaki, T., Momose, Y., Nagata, T.: Localization of the anti-allergic agent tranilast in the urinary bladder of rat as demonstrated by light microscopic radioautography. Drug Res. 40, 272-275, 1990b.

Oguchi, K., Nagata, T.: A radioautographic study of activated satellite cells in dystrophic chicken muscle. In, Current Research in Muscular Dystrophy Japan. The Proc. Ann. Meet. Muscular Dystrophy Res. 1980, pp. 16-17, Ministry of Welfare of Japan, Tokyo, 1980.

Oguchi, K., Nagata, T.: Electron microscopic radioautographic observation on activated satellite cells in dystrophy chickens. In, Clinical Studies on the Etiology of Muscular Dystrophy. Annual Report on Neurological Diseases 1981, pp. 30-33, Ministry of Welfare of Japan, Tokyo, 1981.

Ohno, S., Fujii, Y., Usuda, N., Endo, T., Hidaka, H., Nagata, T.: Demonstration of intracellular localization of calmodulin antagonist by wet-mounting radioautography. J. Electron Microsc. 32, 1-12, 1983.

Ohno, S., Fujii, Y., Usuda, N., Nagata, T., Endo, T., Tanaka, T., Hidaka, H.: Intracellular localization of calmodulin antagonists (W-7). In, Calmodulin and intracellular $\mathrm{Ca}^{2+}$ receptors. Kakiuchi, S., Hidaka, H, Means, A. R., Eds., pp. 39-48, Plenum Publishing Co., New York, 1982.

Olea, M. T.: An ultrastructural localization of lysosomal acid phosphatase activity in aging mouse spleen: a quantitative X-ray microanalytical study. Acta Histochem. Cytochem. 24, 201-208, 1991.

Olea, M. T., Nagata, T.: X-ray microanalysis of cerium in mouse spleen cells demonstrating acid phosphatase activity using high voltage electron microscopy, Cell. Mol. Biol. 37, 155-163, 1991.

Olea, M. T., Nagata, T. : Simultaneous localization of ${ }^{3} \mathrm{H}$-thymidine incorporation and acid phosphatase activity in mouse spleen: EM radioautography and cytochemistry. Cell. Mol. Biol. 38, 115-122, 1992a.

Olea, M. T., Nagata, T.: A radioautographic study on RNA synthesis in aging mouse spleen after ${ }^{3} \mathrm{H}$-uridine labeling in vitro. Cell. Mol. Biol. 38, 399-405, 1992b.

Oliveira, S. F., Nagata, T., Abrahamsohn, P. A., Zorn, T. M. T.: Electron microscopic radioautographic study on the incorporation of ${ }^{3} \mathrm{H}$-proline by mouse decidual cells. Cell. Mol. Biol. 37, 315-323, 1991. 
Oliveira, S. F., Abrahamsohn, P. A., Nagata, T., Zorn, T. M. T.: Incorporation of $3 \mathrm{H}$-amino acids by endometrial stromal cells during decidualization in the mouse. A radioautographical study. Cell. Mol. Biol. 41, 107-116, 1995.

Pearse, A. G. E.: Histochemistry, Theoretical and Applied. 4th Ed. Vol. 1. 439 pp., 1980, Vol. 2. 1055 pp., 1985, Vol. 3. Ed. with P. Stoward, 728 pp. Churchill Livingstone, Edinburgh, London and New York, 1991.

Sakai, Y., Ikado, S., Nagata, T.: Electron microscopic radioautography of satellite cells in regenerating muscles. J. Clin. Electr. Microsc. 10, 508-509, 1977.

Sato, A.: Quantitative electron microscopic studies on the kinetics of secretory granules in Gcells. Cell Tissue Res. 187, 45-59, 1978.

Sato, A., Iida, F., Furihara, R., Nagata, T.: Electron microscopic raioautography of rat stomach G-cells by means of ${ }^{3} \mathrm{H}$-amino acids. J. Clin. Electron Microsc. 10, 358-359, 1977.

Shimizu, T., Usuda, N., Yamanda, T., Sugenoya, A., Iida, F.: Proliferative activity of human thyroid tumors evaluated by proliferating cell nuclear antigen/cyclin immnohistochemical studies. Cancer 71, 2807-2812, 1993.

Sun, L.: Age related changes of RNA synthesis in the lungs of aging mice by light and electron microscopic radioautography. Cell. Mol. Biol. 41, 1061-1072, 1995.

Sun, L., Gao, F., Duan, H., Nagata, T.: Light microscopic radioautography of DNA synthesis in pulmonary cells in aging mice. In, Radioautography in Medicine, Nagata, T. Ed., pp. 201-205, Shinshu University Press, Matsumoto, 1994.

Sun, L., Gao, F., Nagata, T.: Study on the DNA synthesis of pulmonary cells in aging mice by light microscopic radioautography. Cell. Mol. Biol. 41, 851-859, 1995a.

Sun, L., Gao, F., Jin, C., Duan, H., Nagata, T.: An electron microscopic radioautographic study on the DNA synthesis of pulmonary tissue cells in aging mice. Med. Electron. Microsc. 28, 129-131, 1995b.

Sun, L., Gao, F., Jin, C., Nagata, T.: DNA synthesis in the tracheae of aging mice by means of light and electron microscopic radioautography. Acta Histochem. Cytochem. 30, 211-220, 1997a.

Sun, L., Gao, F., Nagata, T.: A Light Microscopic radioautographic study on protein synthesis in pulmonary cells of aging mice. Acta Histochem. Cytochem. 30, 463470, 1997b.

Suzuki, K., Imada, T., Gao, F., Ma, H., Nagata, T.: Radioautographic study of benidipine hydrochloride: localization in the mesenteric artery of spontaneously hypertensive rat. Drug Res. 44, 129-133, 1994.

Terauchi, A., Mori, T., Kanda, H., Tsukada, M., Nagata, T.: Radioautographic study of 3Htaurine uptake in mouse skeletal muscle cells. J. Clin. Electron Microsc. 21, 627-628, 1988.

Terauchi, A., Nagata, T.: Observation on incorporation of ${ }^{3} \mathrm{H}$-taurine in mouse skeletal muscle cells by light and electron microscopic radioautography. Cell. Mol. Biol. 39, 397-404, 1993.

Terauchi, A., Nagata, T.: In corporation of ${ }^{3} \mathrm{H}$-taurine into the blood capillary cells of mouse skeletal muscle. Radioautography in Medicine, Nagata, T. ed., Shinshu University Press, Matsumoto, 1994.

Toriyama, K.: Study on the aging changes of DNA and protein synthesis of bipolar and photo-receptor cells of mouse retina by light and electron microscopic radioautography. Cell. Mol. Biol. 41, 593-601, 1995. 
Tsukahara, S., Yoshida, K., Nagata, T.: A radioautographic study on the incorporation of ${ }^{14} \mathrm{C}$-bupranolol (beta-blocking agent) into the rabbit eye. Histochemistry 68, 237244, 1980.

Usuda, N., Nagata, T.: Electron microscopic radioautography of acyl-CoA mRNA by in situ hybridization. J. Clin. Electron Microsc. 25, 332-333, 1992.

Usuda, N., Nagata, T.: The immunohistochemical and in situ hybridization studies on hepatic peroxisomes. Acta Histochem. Cytochem. 28, 169-172, 1995.

Usuda, N., Hanai, T., Morita, T., Nagata, T.: Radioautographic demonstration of peroxisomal acyl-CoA oxidase mRNA by in situ hybridization. In, Recent advances in cellular and molecular biology, Vol. 6. Molecular biology of nucleus, peroxisomes, organelles and cell movement. Wegmann, R. J., Wegmann, M., Eds, pp.181-184, Peeters Press, Leuven, 1992.

Uwa, H., Nagata, T.: Cell population kinetics of the scleroblast during ethisterone-induced anal-fin process formation in adult females of the Medaka. Dev. Growth Different. 9, 693-694, 1976.

Watanabe, I., Makiyama, M. C. K., Nagata, T.: Electron microscopic radioautographic observation of the submandibular salivary gland of aging mouse. Acta Microscopica 6. 130-131, 1997.

Yamabayashi, S., Gunarso, W., Tsukahara, S., Nagata, T.: Incorporation of ${ }^{3} \mathrm{H}-$ befunolol (beta blocking agent) into melanin granules of ocular tissues in the pigmented rabbits. I. Light microscopic radioautography. Histochemistry 73, 371-375, 1981.

Yamada, A. T.: Timely and topologically defined protein synthesis in the periimplanting mouse endometrium revealed by light and electron microscopic radioautography. Cell. Mol. Biol. 39, 1-12, 1993.

Yamada, A., Nagata, T.: Ribonucleic acid and protein synthesis in the uterus of pregnant mouse during activation of implantation window. Med. Electron Microsc. 27, 363365, 1992a.

Yamada, A., Nagata, T.: Light and electron microscopic raioautography of DNA synthesis in the endometria of pregnant-ovariectomized mice during activation of implantation window. Cell. Mol. Biol. 38, 763-774, 1992b.

Yamada, A., Nagata, T.: Light and electron microscopic raioautography of RNA synthesis of peri-implanting pregnant mouse during activation of receptivity for blastocyst implantation. Cell. Mol. Biol. 38, 211-233, 1993.

Yoshinaga, K.: Uterine receptivity for blastcyst implantation. Ann. N. Y. Acad. Sci. USA, 541, 424-431, 1988.

Yoshizawa, S., Nagata, A., Honma, T., Oda, M., Murata, F., Nagata, T.: Study of ethionine pancreatitis by means of electron microscopic radioautography. J. Clin. Electron Microsc. 7, 349-350, 1974.

Yoshizawa, S., Nagata, A., Honma, T., Oda, M., Murata, F., Nagata, T.: Radioautographic study of protein synthesis in pancreatic exocrine cells of alcoholic rats. J. Clin. Electron. Microsc. 10, 372-373, 1977. 


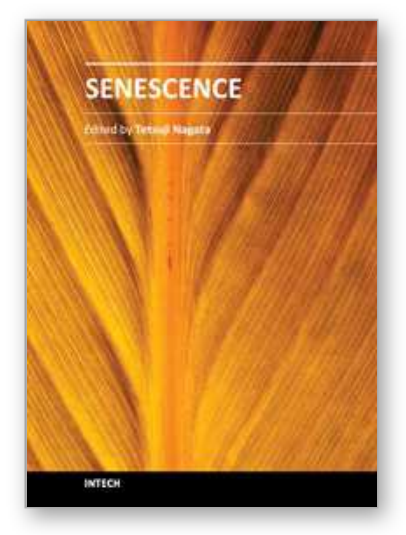

\author{
Senescence \\ Edited by Dr. Tetsuji Nagata
}

ISBN 978-953-51-0144-4

Hard cover, 850 pages

Publisher InTech

Published online 29, February, 2012

Published in print edition February, 2012

The book "Senescence" is aimed to describe all the phenomena related to aging and senescence of all forms of life on Earth, i.e. plants, animals and the human beings. The book contains 36 carefully reviewed chapters written by different authors, aiming to describe the aging and senescent changes of living creatures, i.e. plants and animals.

\title{
How to reference
}

In order to correctly reference this scholarly work, feel free to copy and paste the following:

Tetsuji Nagata (2012). Macromolecular Synthesis in the Digestive and Respiratory Systems, Senescence, Dr. Tetsuji Nagata (Ed.), ISBN: 978-953-51-0144-4, InTech, Available from:

http://www.intechopen.com/books/senescence/macromolecular-synthesis-in-the-digestive-and-respiratorysystems

\section{INTECH}

open science | open minds

\author{
InTech Europe \\ University Campus STeP Ri \\ Slavka Krautzeka 83/A \\ 51000 Rijeka, Croatia \\ Phone: +385 (51) 770447 \\ Fax: +385 (51) 686166 \\ www.intechopen.com
}

\author{
InTech China \\ Unit 405, Office Block, Hotel Equatorial Shanghai \\ No.65, Yan An Road (West), Shanghai, 200040, China \\ 中国上海市延安西路65号上海国际贵都大饭店办公楼405单元 \\ Phone: +86-21-62489820 \\ Fax: $+86-21-62489821$
}


(C) 2012 The Author(s). Licensee IntechOpen. This is an open access article distributed under the terms of the Creative Commons Attribution 3.0 License, which permits unrestricted use, distribution, and reproduction in any medium, provided the original work is properly cited. 